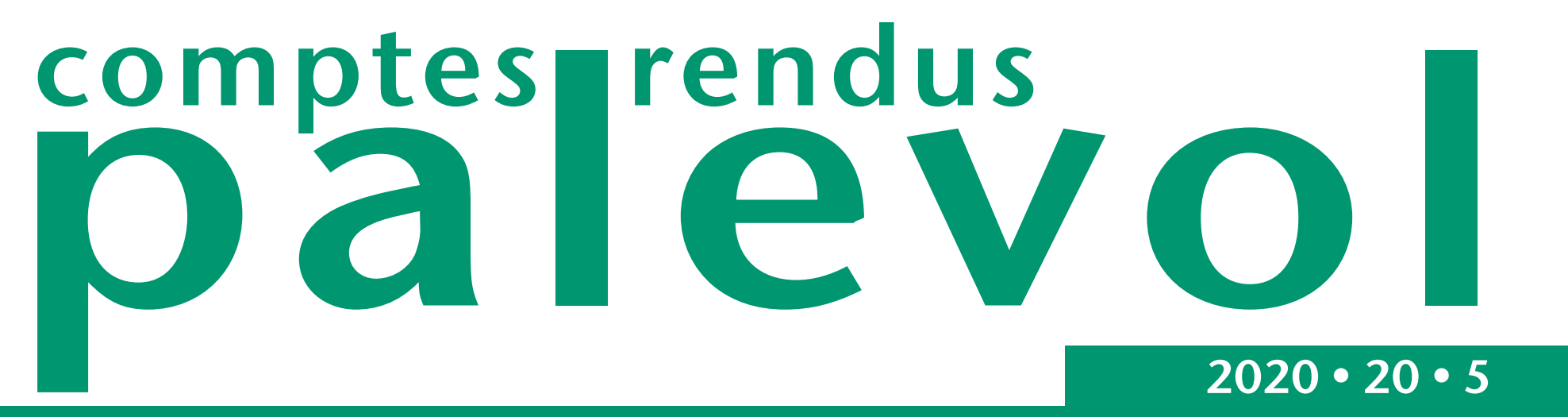

The stapes of Thrinaxodon Seeley, 1894 and Galesaurus Owen, 1859: a case of study for intraspecific variability in basal cynodonts

Leandro C. GAETANO \& Fernando ABDALA
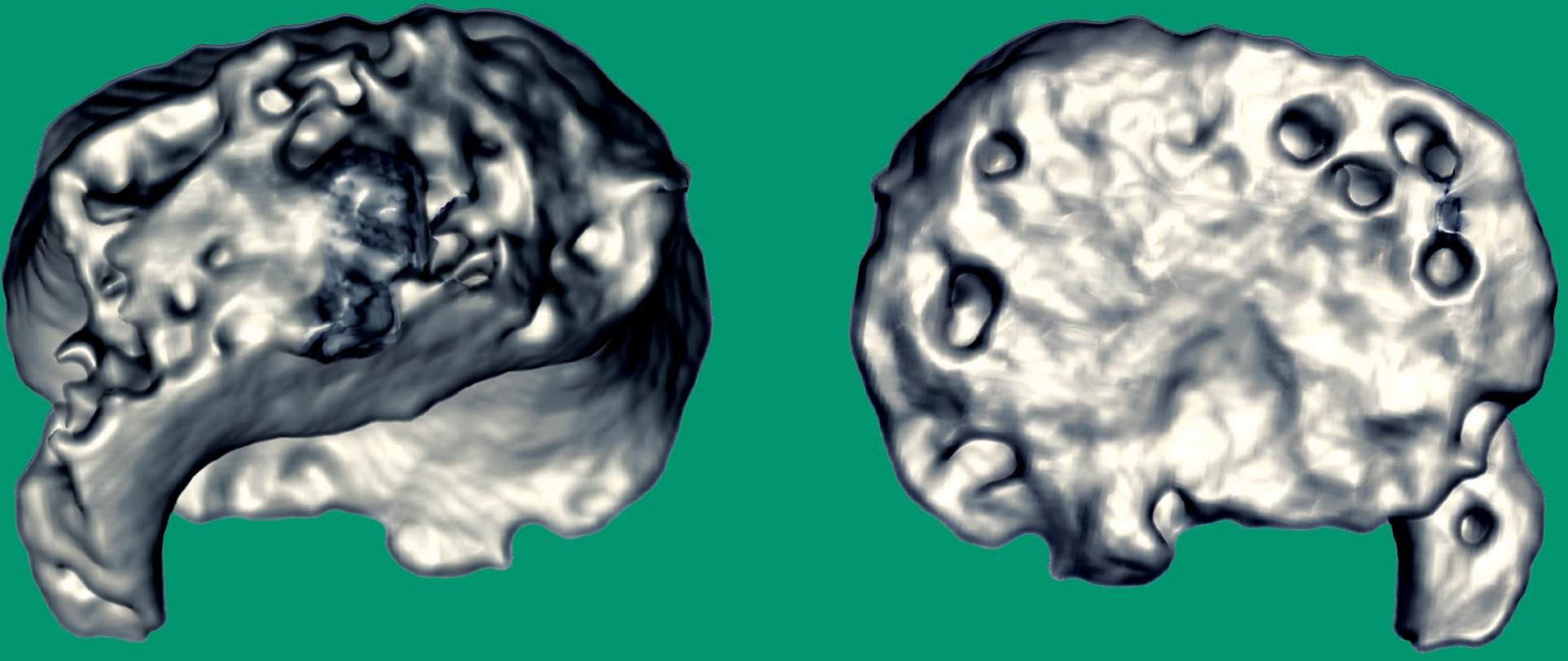

art. 20 (5) - Published on 8 February 2021

www.cr-palevol.fr 
DiRECTEURS DE LA PUBLICATION / PUBLICATION DIRECTORS:

Bruno David, Président du Muséum national d'Histoire naturelle

Étienne Ghys, Secrétaire perpétuel de l'Académie des sciences

RÉDACTEURS EN CHEF / EDITORS-IN-CHIEF: Michel Laurin (CNRS), Philippe Taquet (Académie des sciences)

AssistANTE DE RÉDACTION / AssistANT EDITOR: Adeline Lopes (Académie des sciences ; cr-palevol@academie-sciences.fr)

MISE EN PAGE / PAGE LAYOUT: Fariza Sissi (Muséum national d'Histoire naturelle ; fariza.sissi@mnhn.fr)

ÉDITEURS ASSOCIÉS / ASSOCIATE EDITORS: $\left({ }^{*}\right.$, took charge of the editorial process of the article/a pris en charge le suivi éditorial de l'article)

Amniotes du Mésozoïque/Mesozoic amniotes

Hans-Dieter Sues* (Smithsonian National Museum of Natural History, Washington)

Lépidosauromorphes/Lepidosauromorphs

Hussam Zaher (Universidade de São Paulo)

Métazoaires/Metazoa

Annalisa Ferretti (Università di Modena e Reggio Emilia, Modena)

Micropaléontologie/Micropalaeontology

Maria Rose Petrizzo (Université de Milan)

Palaeoanthropology

R. Macchiarelli (Université de Poitiers, Poitiers)

Paléobotanique/Palaeobotany

Evelyn Kustatscher (The Museum of Nature South Tyrol, Bozen/Bolzano)

Paléoichthyologie/Palaeoichthyology

Philippe Janvier (Muséum national d'Histoire naturelle, Académie des sciences, Paris)

Palaeomammalogy (small mammals)

L. van den Hoek Ostende (Naturalis Biodiversity Center, CR Leiden)

Palaeomammalogy (large and mid-sized mammals)

L. Rook (Università degli Studi di Firenze, Firenze)

Prehistorical archaeology

M. Otte (Université de Liège, Liège)

Tortues/Turtles

Juliana Sterli (CONICET, Museo Paleontológico Egidio Feruglio, Trelew, Argentine)

COUVERTURE / COVER:

Left stapes of Thrinaxodon: lateral and medial view. CT-scan images of Thrinaxodon specimen BP/1/7199 kindly provided by Dr. V. Fernandez (NHMUK).

Comptes Rendus Palevol est indexé dans / Comptes Rendus Palevol is indexed by:

- Cambridge Scientific Abstracts

- Current Contents ${ }^{\circ}$ Physical

- Chemical, and Earth Sciences ${ }^{\circledR}$

- ISI Alerting Services ${ }^{\circledR}$

- Geoabstracts, Geobase, Georef, Inspec, Pascal

- Science Citation Index ${ }^{\circledR}$, Science Citation Index Expanded ${ }^{\circledR}$

- Scopus ${ }^{\circledR}$.

Les articles ainsi que les nouveautés nomenclaturales publiés dans Comptes Rendus Palevol sont référencés par / Articles and nomenclatural novelties published in Comptes Rendus Palevol are registered on:

- ZooBank ${ }^{\circledR}$ (http://zoobank.org)

Comptes Rendus Palevol est une revue en flux continu publiée par les Publications scientifiques du Muséum, Paris et l'Académie des sciences, Paris Comptes Rendus Palevol is a fast track journal published by the Museum Science Press, Paris and the Académie des sciences, Paris

Les Publications scientifiques du Muséum publient aussi / The Museum Science Press also publish:

Adansonia, Geodiversitas, Zoosystema, Anthropozoologica, European Journal of Taxonomy, Naturae, Cryptogamie sous-sections Algologie, Bryologie, Mycologie.

L'Académie des sciences publie aussi / The Académie des sciences also publishes:

Comptes Rendus Mathématique, Comptes Rendus Physique, Comptes Rendus Mécanique, Comptes Rendus Chimie, Comptes Rendus Géoscience, Comptes Rendus Biologies.

Diffusion - Publications scientifiques Muséum national d'Histoire naturelle

CP 41 - 57 rue Cuvier F-75231 Paris cedex 05 (France)

Tél. : 33 (0)1 40794805 / Fax: 33 (0)1 40793840

diff.pub@mnhn.fr / https://sciencepress.mnhn.fr

Académie des sciences, Institut de France, 23 quai de Conti, 75006 Paris.

(C) Publications scientifiques du Muséum national d'Histoire naturelle / ( ) Académie des sciences, Paris, 2021

ISSN (imprimé / print): 1631-0683/ ISSN (électronique / electronic): 1777-571X 


\section{The stapes of Thrinaxodon Seeley, 1894 and Galesaurus Owen, 1859: a case of study for intraspecific variability in basal cynodonts}

Leandro C. GAETANO

Departamento de Ciencias Geológicas, FCEyN, Instituto de Estudios Andinos 'Don Pablo Groeber', IDEAN (Universidad de Buenos Aires, CONICET), Intendente Güiraldes 2160, Ciudad Universitaria - Pabellón II, C1428EGA,

Ciudad Autónoma de Buenos Aires (Argentina) and Evolutionary Studies Institute, University of the Witwatersrand, Private Bag 3, WITS 2050, Johannesburg (South Africa) Icgaetano@gl.fcen.uba.ar (corresponding author)

Fernando ABDALA

Evolutionary Studies Institute, University of the Witwatersrand,

Private Bag 3, WITS 2050, Johannesburg (South Africa) and Unidad Ejecutora Lillo, CONICET-Fundación Miguel Lillo, Miguel Lillo 251, 4000, San Miguel de Tucumán, Tucumán (Argentina) 1viutiabdala2@gmail.com

Submitted on 16 August 2019 | Accepted on 6 January 2020 | Published on 8 February 2021

urn:Isid:zoobank.org:pub:6EF4C5AA-C9D5-4F5D-9934-B42690472301

Gaetano L. C. \& Abdala F. 2021. - The stapes of Thrinaxodon Seeley, 1894 and Galesaurus Owen, 1859: a case of study for intraspecific variability in basal cynodonts. Comptes Rendus Palevol 20 (5): 57-74. https://doi.org/10.5852/cr-palevol2021v20a5

\section{ABSTRACT}

We surveyed the stapedial anatomy of Thrinaxodon liorhinus Seeley, 1894 and Galesaurus planiceps Owen, 1859, two iconic Early Triassic basal cynodonts. The complete characterization of this bone and the analysis of its morphological variability along the ontogeny within each taxon were possible through the study of eleven elements of Thrinaxodon Seeley, 1894 and nine of Galesaurus Owen, 1859.

KEY WORDS

Stapes,

epicynodontia

Thrinaxodon,

Early Triassic. Our results highlight notable qualitative and quantitative differences among specimens of the same species. Stapes growth model in Galesaurus shows a positive allometry on the lateromedial length and on the anteroposterior width, whereas in Thrinaxodon there is a negative allometry in the anteroposterior width but the lateromedial length is isometric. This study offers a counterintuitive result of inordinate high intraspecific morphological variation of the stapes of basal non-mammaliaform cynodonts. 


\begin{abstract}
RÉSUMÉ
L'étrier de Thrinaxodon Seeley, 1894 et Galesaurus Owen, 1859 : une étude de cas de la variation intraspécifique dans les cynodontes basaux.

Nous analysons l'anatomie de l'étrier de Thrinaxodon liorhinus Seeley, 1894 et Galesaurus planiceps Owen, 1859, deux cynodontes emblématiques du Trias Inférieur. La caractérisation intégrale de cet os et l'analyse de sa variabilité morphologique au long de l'ontogenèse dans chaque taxon ont été rendues possibles par l'étude de onze éléments de Thrinaxodon Seeley, 1894 et de neuf éléments de Galesaurus Owen, 1859. Nos résultats mettent en évidence des différences qualitatives et quantitatives notables entre les spécimens d'une même espèce. Le modèle de croissance de l'étrier de Galesaurus montre une allométrie positive dans sa longueur latéromédiale et sa largeur antéropostérieure, alors que chez Thrinaxodon il y a une allométrie négative dans la largeur antéropostérieure de l'étrier tandis que sa longueur est isométrique. Cette étude fournit un résultat contre-intuitif, montrant une variation morphologique intraspécifique de l'étrier excessivement élevée parmi les cynodontes non mammaliaformes basaux.

\section{MOTS CLÉS Étrier, epicynodontia, Thrinaxodon, \\ Trias Inférieur.}

\section{INTRODUCTION}

Thrinaxodon liorhinus Seeley, 1894 and Galesaurus planiceps Owen, 1959 are well-represented basal epicynodonts from the Early Triassic of Gondwana. Thrinaxodon Seeley, 1894 has been found in Antarctica, India, and South Africa whereas the Galesarurus Owen, 1859 record is up to now restricted to South Africa (see Abdala 2003; Butler 2009; Abdala \& Ribeiro 2010; Butler et al. 2019). Since the original description by Owen (1887) and the final re-classification by Seeley (1894), Thrinaxodon has been the prime subject of numerous studies since the early twentieth century (see historical accounts by Fourie 1974; Abdala et al. 2013; Jasinoski et al. 2015) as it has been considered a key source for understanding the early evolution of mammalian characteristics. Several papers on the cranial (Owen 1887; Parrington 1936, 1946; Broom 1938; Olson 1944; Brink 1955; Estes 1961; Crompton 1963; Hopson 1966; Van Herden 1972; Osborn \& Crompton 1973; Fourie 1974; Gow 1985; Rowe et al. 1993; Abdala et al. 2013) and postcranial (e.g. Jenkins 1971) anatomy of this taxon have been published. Galesarurus was initially recognized by Owen $(1859,1860)$ and has also been subject of several studies. Most of them have focussed on its cranial anatomy (Owen 1876; Watson 1920; Broom 1932; Parrington 1934; Rigney 1938; Brink 1965; Van Heerden 1972; Abdala 2003; Pusch et al. 2019) whereas the postcranium has been partially studied (e.g. Parrington 1934; Kemp 1969; Jenkins 1971; Panko 2001; Kümmell 2009) although a thorough description based in several specimens has been recently presented (Butler 2009; Butler et al. 2019). Additionally, the histology, ontogeny and palaeobiology of these taxa have been surveyed (e.g. Haughton 1924; Damiani et al. 2003; Botha \& Chinsamy 2005; Abdala et al. 2006, 2013; Botha-Brink et al. 2012; Fernandez et al. 2013; Jasinoski et al. 2015; Jasinoski \& Abdala 2017b; Butler et al. 2019). Considering their palaeoecology, both Thrinaxodon and Galesaurus are frequently found as complete skeletons (Jasinoski \& Abdala 2017a), preserving delicate bones such as stapes and hyoids, which clearly indicates they have been fossilized in a protected environment. Thrinaxodon was considered as an active digger (Damiani et al. 2003; Kümmell \& Frey 2012; Fernandez et al. 2013) but anterior limb traits as well as palaeohistological features are not in agreement on this proposed behaviour and suggest it may have used excavations made by other animals. On the other hand, the robust forelimb bones of Galesaurus with thick cortices suggest that it was more likely an active digger (Butler et al. 2019). Thrinaxodon is the representative of basal cynodonts in most papers dealing with the audition in non-mammaliaform cynodonts and the evolution of the hearing-related structures in synapsids (Parrington 1946, 1979; Watson 1953; Estes 1961; Hopson 1966; Fourie 1974; Allin 1975; Allin \& Hopson 1992; Luo \& Crompton 1994; Maier \& Ruf 2016). On the other hand, Galesaurus has usually not been considered when discussing such topics. This situation is also echoed in the knowledge on the stapedial anatomy of these taxa. The stapedial anatomy of Galesaurus remained obscure apart from the short descriptions provided by Watson (1920), Parrington (1934), and most recently Pusch et al. (2019).The stapes of juvenile and adult individuals of Thrinaxodon has been analysed in relatively more detail (Parrington 1946; Watson 1953; Estes 1961; Hopson 1966; Fourie 1974; Allin 1975; Allin \& Hopson 1992). However, these earlier studies centred on the general features of the stapes, its contacts with adjacent bones, and the characteristics of purported links with the hypothesized tympanic membrane. A detailed account of the stapedial anatomy as well as the analysis of its intraspecific variation in Thrinaxodon and Galesaurus is long overdue.

Several specimens of Thrinaxodon and Galesaurus with associated stapes were available to us for the present study (Figs 1;2). These specimens are a good sample of the size variation in these taxa (Tables 1;2), representing different ontogenetic stages (Jasinoski et al. 2015; Jasinoski \& Abdala 2017b). The availability of such a large sample of Thrinaxodon and Galesaurus stapes constitutes an unparalleled opportunity to fully characterize this bone and analyse its variations in an ontogenetic context. 
ABBREVIATIONS

Institutions

AMNH American Museum of Natural History, New York;

BP Evolutionary Studies Institute (formerly Bernard Price Institute for Palaeontological Research), University of the Witwatersrand, Johannesburg;

SAM-PK-K Karoo collection, Iziko South African Museum, Cape Town;

NMP KwaZulu-Natal Museum, Pietermaritzburg;

NMQR National Museum, Bloemfontein;

RC Rubidge Collection, Wellwood, Graaff Reinet;

TM Ditsong National Museum of Natural History (formerly Transvaal Museum), Pretoria;

UCMP Museum of Paleontology, University of California, Berkeley;

UMCZ University Museum of Zoology, Cambridge.

Others

BSL basal skull length;

LS least square;

RMA reduced major axis.

\section{MATERIAL AND METHODS}

The stapes of Thrinaxodon and Galesaurus has been recorded in several specimens. Eleven Thrinaxodon specimens (BP/1/1375, $\mathrm{BP} / 1 / 4280, \mathrm{BP} / 1 / 5208, \mathrm{BP} / 1 / 5372$, BP/1/7199, TM 80a, TM 80b, TM 81, TM 377, TM 782 and NMQR 811) and nine Galesaurus specimens (AMNH 2223, BP/1/4597, NMP581, NMQR 860, NMQR 1451, RC 845, SAM-PKK1119, SAM-PK-K9956 and UMCZ T819) were accessible for our study. Other stapes that were accessed but not measured are UCMP 40466, UCMP 42877 and UCMP 42878. The stapes studied are mainly preserved in natural position in the skull or only slightly displaced; hence, they are usually observed in ventral aspect and occasionally the posterior view is available. Only in a few cases, the stapes were completely prepared and separated from the skull. There are no signs that suggest that mechanical or chemical preparation altered the original morphology of the stapes. Available micro-CT-scans allowed for the three dimensional observation of the stapes in two Thrinaxodon specimens (BP/1/5372, BP/1/7199). The taxonomic identification of the stapes is based on the well-known cranial anatomy of the specimens analysed. Measurements were taken directly from the specimens using a digital calliper (Black Jack, model D056) or from digital photographs using the software Image-J 1.50i. Our basal skull length measurements agreed with those of Abdala et al. (2013), Jasinoski et al. (2015) and Jasinoski \& Abdala (2017b). For clarity of expression, we will use "length" to refer to the longest dimension of a structure whereas "width" will be employed to describe its shortest dimension (Fig. 3).

The entire sample studied is from the South African Karoo Basin. Finding localities and stratigraphic levels of the studied specimens are presented in Table 3. The surveyed Thrinaxodon specimens come from the South African localities of Harrismith (six specimens) and Bethulie (one specimen) in the Free State Province and Bergville (two specimens) in Kwa-Zulu Natal Province; specimens of Galesaurus were recovered from
Harrismith (four specimens) and Bethulie (three specimens). In Bethulie, it is represented the lower and middle part of the Katberg Formation. In Harrismith, the discoveries are from the Harrismith Member of the Normandien Formation, correlated with the Palingkloof Member of the Balfour Formation. In Bergville, the specimens also come from the Harrismith Member (Fernandez et al. 2013). All these records are circumscribed to the Induan (Smith \& Botha-Brink 2014) corresponding to lower levels of the Lystrosaurus AZ. Hence, there are no major temporal differences represented in the sample analysed here.

The basal skull length (BSL; as measured from the anteriormost tip of the snout to the posterior margin of the occipital condyles) was used as an estimative of the ontogenetic stage of the individuals of each species, with larger specimens representing older, mature, individuals. This allowed classifying the available specimens into ontogenetic categories as proposed by Jasinoski et al. (2015) and Jasinoski \& Abdala (2017b). The stapedial anatomy will be described in the following section from the smaller to the larger specimens available of each taxa.

The software PAST v.3.25 (Hammer et al. 2001) was employed to evaluate the allometry of the lateromedial stapedial length and the anteroposterior stapedial width, with the basal skull length selected as independent variable. The measurements were log-transformed for the analysis and the slope of the equation interpreted as the coefficient of allometry. Values of this coefficient are presented under Reduced Major Axis (RMA) and Least Square (LS) methods that differ in the way they deal with error of the variables (Hammer 2019).

\section{STAPEDIAL ANATOMY AND INTRASPECIFIC VARIATION}

As in other non-mammaliaform cynodonts, the stapes of Thrinaxodon and Galesaurus can be described as bicrurated with a dorsoventrally oriented stapedial foramen (see Gaetano \& Abdala 2015). The crura are fused together medially and laterally into platforms to a varying degree in different specimens. In some specimens, despite fused, the individuality of the crura can still be recognized on the platforms whereas in others they are indistinguishable. The term "platform" is employed here without implying a supporting role of any sort (Gaetano \& Abdala 2015). The medial portion of the stapes is the stapedial footplate, which contacted with the fenestra ovalis. Laterally, the stapes articulated with the quadrate. A dorsal process rising from the posterior crus is recognized in some of the specimens analysed.

\section{THRINAXODON}

The stapes of Thrinaxodon is a gracile bone constituted by two crura that fuse medially and laterally delimiting a relatively large ovoid stapedial foramen (Fig. 1). The anterior crus is large and more robust than the delicate, thin posterior crus. The fused portions of the crura are usually extended as lateral and medial platforms. In ventral view, the margin of the stapedial footplate at the bone's medial end is almost invariable projected 
TABLE 1. - Measurements (in millimetres) of the basal skull length and stapes of the analysed specimens of Thrinaxodon Seeley, 1894. Ontogenetic stage after Jasinoski et al. (2015). Asterisk indicates that the measurement is approximated. Skull width measured at the level of the quadrate.

\begin{tabular}{|c|c|c|c|c|c|c|c|c|c|c|}
\hline Specimen & $\begin{array}{l}\text { Basal } \\
\text { skull } \\
\text { length }\end{array}$ & $\begin{array}{l}\text { Skull } \\
\text { width }\end{array}$ & $\begin{array}{l}\text { Laterome- } \\
\text { dial stapes } \\
\text { length }\end{array}$ & $\begin{array}{l}\text { Anteropos- } \\
\text { terior } \\
\text { stapes width }\end{array}$ & $\begin{array}{l}\text { Laterome- } \\
\text { dial stape- } \\
\text { dial foramen } \\
\text { length }\end{array}$ & $\begin{array}{l}\text { Antero- } \\
\text { posterior } \\
\text { stapedial } \\
\text { foramen width }\end{array}$ & $\begin{array}{l}\text { Anteroposte- } \\
\text { rior anterior } \\
\text { crus width }\end{array}$ & $\begin{array}{l}\text { Anteroposte- } \\
\text { rior posterior } \\
\text { crus width }\end{array}$ & $\begin{array}{l}\text { Stape- } \\
\text { dial foot- } \\
\text { plate area } \\
\left(\mathrm{mm}^{2}\right)\end{array}$ & $\begin{array}{l}\text { Ontogenetic } \\
\text { stage }\end{array}$ \\
\hline $\mathrm{BP} / 1 / 5372$ & 37 & 28.3 & 2.37 & 1.74 & 1.47 & 0.99 & 0.52 & 0.23 & 3.43 & $\begin{array}{l}\text { early juvenile } \\
\text { non-juvenile }\end{array}$ \\
\hline TM 80a & 56 & 36.24 & 4.67 & 2.32 & 1.40 & 1.42 & 0.72 & 0.21 & - & $\begin{array}{l}\text { or subadult } \\
\text { non-juvenile }\end{array}$ \\
\hline TM 80b & 69 & $44.08^{\star}$ & 5.58 & 2.25 & 2.68 & 1.12 & 0.66 & 0.47 & - & adult \\
\hline TM 782 & 70 & $54.06^{\star}$ & 6.24 & 2.60 & 3.46 & 1.55 & 0.72 & 0.28 & - & adult \\
\hline BP/1/5208 & 73 & 53.23 & 5.27 & 2.73 & 2.70 & 1.58 & 0.76 & 0.44 & - & adult \\
\hline BP/1/7199 & 75 & 41.57 & 4.55 & 2.66 & 2.23 & 1.65 & 0.80 & 0.25 & 6.52 & adult \\
\hline TM 377 & 77 & $56.50^{\star}$ & 5.63 & 2.84 & 1.72 & 1.46 & 0.84 & 0.51 & - & adult \\
\hline NMQR811 & 80 & - & 5.08 & 2.14 & 1.77 & 1.23 & 0.61 & 0.32 & 5.86 & adult \\
\hline TM 81 & 80 & $36.58^{\star}$ & 6.32 & 2.69 & 3.45 & 1.55 & 0.85 & 0.24 & - & adult \\
\hline $\mathrm{BP} / 1 / 1375$ & 81 & $57.74^{\star}$ & 6.67 & 2.86 & 3.51 & 1.55 & 0.91 & $0.43^{\star}$ & - & adult \\
\hline
\end{tabular}

ventrally, anteriorly and posteriorly. A posterior projection of the lateral margin is often present. A robust dorsal process emerges from the posterior area of the lateral platform, and the base of this process is expanded and further extends onto the lateralmost part of the posterior crus, in some specimens. In ventral view, the lateral margin of the stapes is convex and two portions can be distinguished: a posterior sector, which contacted the quadrate, and an anterior sector, facing anterolaterally and free from the quadrate. The stapedial footplate is larger than the lateral surface of the stapes and, in most of the specimens, circular in medial view. This generalized stapedial structure presents many variations, particularly in the relative development of the different structures that are not always correlated with differences in the size of the specimens.

The stapes of BP/1/5372 was analysed through CT-scan images as direct observation was precluded by other bones. The perfectly preserved right stapes is displaced and rotated so that the stapedial footplate is lateral and the area for the quadrate contact medial. The left stapes is out of place and lacking the posterior crus. The stapes is the less elongated among the studied specimens (Figs 1A; 4A, B) with its antero-posterior width representing about $73 \%$ of the length (Tables $1 ; 4)$. In addition, $\mathrm{BP} / 1 / 5372$ has the proportionally largest stapedial foramen (foramen/stapes length aspect ratio is approximately 0.62 ). The medial platform is poorly developed and restricted to the fusion of the crura. The lateral platform is only slightly wider than the medial one. The footplate is concave and circular and the lateral contact with the quadrate seems to be anteroposteriorly elongated (Fig. 4A, B). It is not possible to ascertain the presence of a dorsal process in the CT-images available to us.

TM 80a preserves both stapes but not in original positions. The right stapes is better exposed but flipped so the dorsal aspect is visible (Fig. 1B). As in most of the stapes analysed, the length of the stapes is twice the width of the bone (Tables $1 ; 4$ ). The width difference between the anterior and posterior crura of TM $80 \mathrm{a}(29 \%)$ is the largest in the sample. The second largest posterior/anterior crural width aspect ratio is $28 \%$ in the large adult specimen TM 81 . The stapedial foramen is small and circular, the only specimen in which the width to length foramen aspect ratio is $c$. 1 . The medial platform is narrower than the lateral one. In TM 80a, the laterally exposed left stapes shows a faint crest dividing the facet for the quadrate contact from the anterolaterally-facing free portion. A dorsal process is not present.

$\mathrm{BP} / 1 / 4280$ left stapes is better exposed in ventral view (Fig. 1C) than the right one. The medium-sized foramen has a length approximately at $46 \%$ of the stapedial length. This is the most elongated foramen among specimens available, being its width 38\% of its length. Medial and lateral platforms are narrow and of similar lateromedial extension. The stapedial footplate seems to be more oval than circular. Unlike other specimens, except the largest of the sample (BP/1/1375), there is a well-developed robust projection of the anterolateral corner of the stapes. The presence of a dorsal process cannot be asserted.

TM 80b right stapes is nearly complete, with only the central portion of the posterior crus missing (Fig. 1D). The difference in width between the crura in ventral view appears as remarkably less pronounced than in the other specimens (posterior/anterior crus width aspect ratio: 0.71 ; Tables $1 ; 4$ ). The medial and lateral platforms are of similar width; however, the medial is slightly wider than the lateral one. A dorsal process is present on the posterolateral region of the stapes, but an informative description is precluded.

The slightly displaced left stapes of TM 782 is almost completely preserved except for its damaged lateral portion (Fig. 1E). The stapedial foramen is slightly longer regarding the length of the stapes when compared to other adult (except the two largest ones, TM 81 and BP/1/1375) and even subadult specimens (Tables 1; 4; Fig. 1D-E). The medial platform is slightly wider than the lateral one. It is not possible to ascertain the presence of a dorsal process.

In BP/1/5208, both stapes are preserved out of place. The right stapes is represented by the flipped anterior portion (observable in dorsal aspect) whereas the posterior crus is missing. A more complete left stapes is available in ventral view, although the posterior crus is poorly preserved (Fig. 1F). 
A

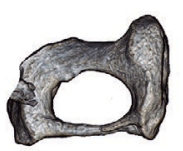

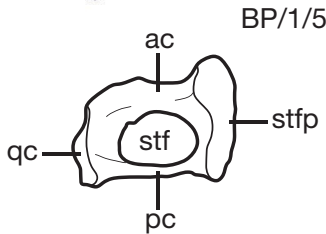

D
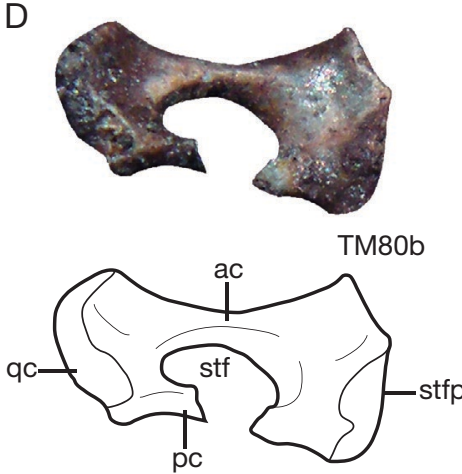

G

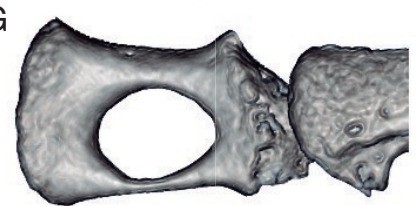

B

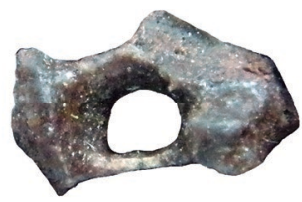

TM80a
C
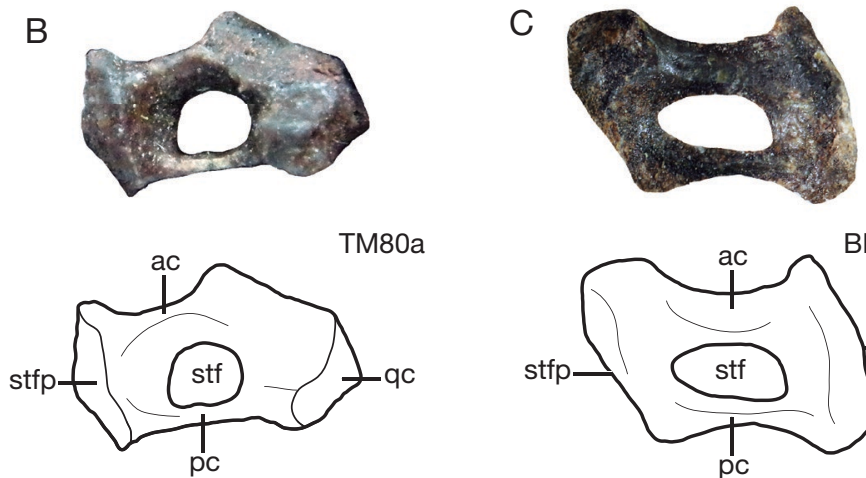

E
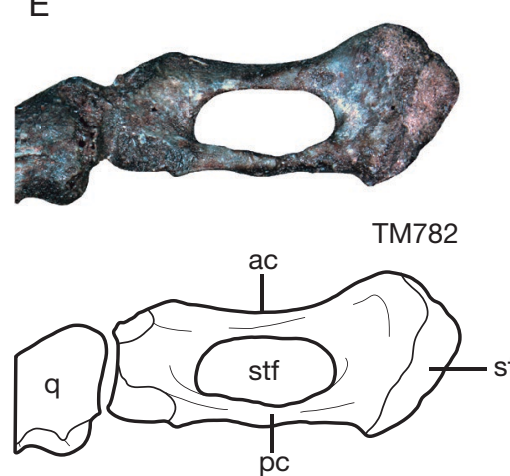

$\mathrm{H}$
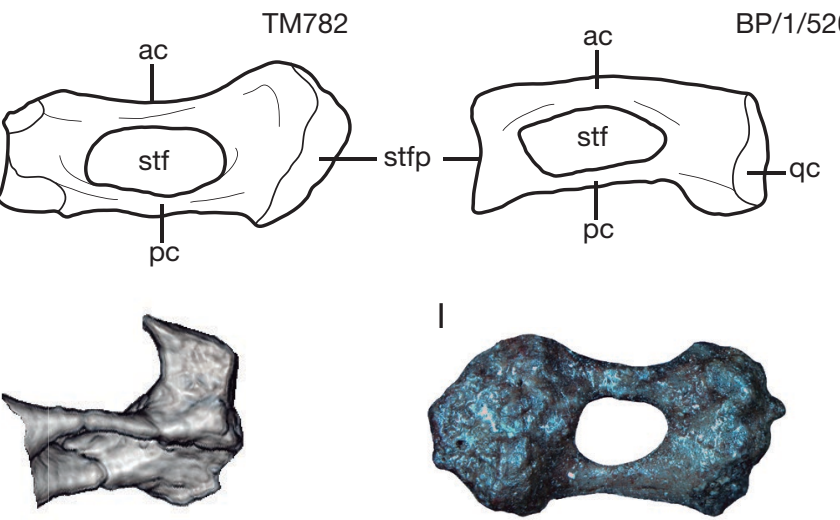

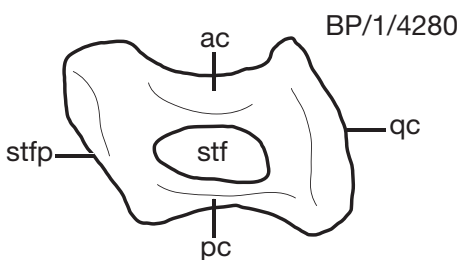

F

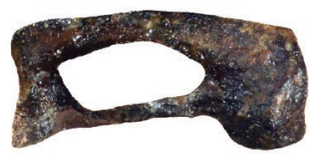

BP/1/5208

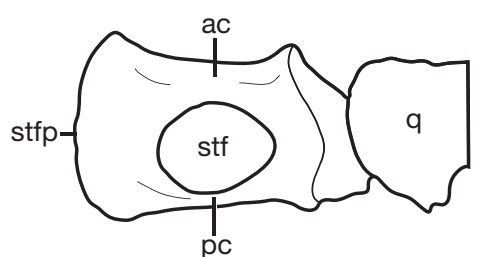

BP/1/7199
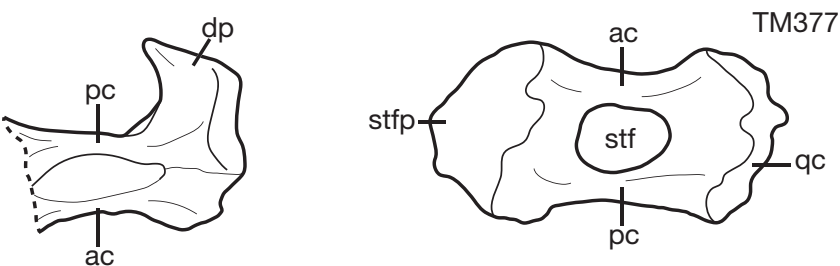

J

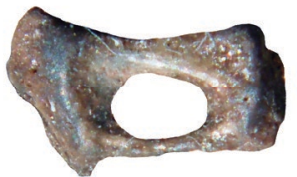

K

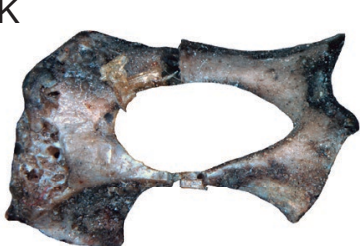

L

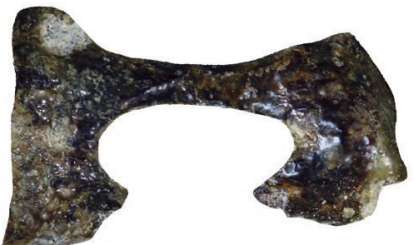

NMQR811
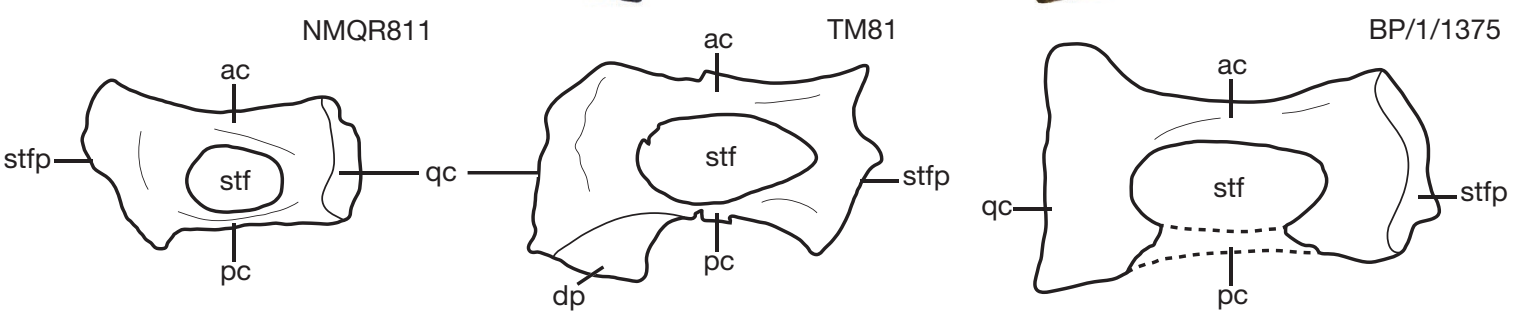

FIG. 1. - Stapes of Thrinaxodon Seeley, 1894: A, right stapes of BP/1/5372 in ventral view; B, right stapes of TM 80a in dorsal view; C, left stapes of BP/1/4280 in ventral view; D, right stapes of TM $80 \mathrm{~b}$ in ventral view; E, left stapes of TM 782 in ventral view; $\mathbf{F}$, left stapes of BP/1/5208 in ventral view; G, H, left stapes of BP/1/7199; G, ventral; H, posteroventral views; I, left stapes of TM 377 in ventral view; J, left stapes of NMQR811 in ventral view; K, right stapes of TM 81 in ventral view; L, right stapes of BP/1/1375 in ventral view. Abbreviations: ac, anterior crus; dp, dorsal process; pc, posterior crus; q, quadrate; qc, quadrate contact area; stf, stapedial foramen; stfp, stapedial footplate. Dashed lines indicate fractures or incomplete margins. Scale bar: $5 \mathrm{~mm}$. 
TABLE 2. - Measurements (in millimetres) of the basal skull length and stapes of the analysed specimens of Galesaurus Owen, 1859. Ontogenetic stage after Jasinoski \& Abdala 2017b. Asterisk indicates that the measurement is approximated. Skull width measured at the level of the quadrate.

\begin{tabular}{|c|c|c|c|c|c|c|c|c|c|c|}
\hline Specimen & $\begin{array}{l}\text { Basal } \\
\text { skull } \\
\text { length }\end{array}$ & $\begin{array}{l}\text { Skull } \\
\text { width }\end{array}$ & $\begin{array}{l}\text { Laterome- } \\
\text { dial stapes } \\
\text { length }\end{array}$ & $\begin{array}{l}\text { Anteropos- } \\
\text { terior stapes } \\
\text { width }\end{array}$ & $\begin{array}{l}\text { Laterome- } \\
\text { dial stape- } \\
\text { dial foramen } \\
\text { length }\end{array}$ & $\begin{array}{l}\text { Anteropos- } \\
\text { terior stape- } \\
\text { dial foramen } \\
\text { width }\end{array}$ & $\begin{array}{l}\text { Anteroposte- } \\
\text { rior anterior } \\
\text { crus width }\end{array}$ & $\begin{array}{l}\text { Anteroposte- } \\
\text { rior posterior } \\
\text { crus width }\end{array}$ & $\begin{array}{l}\text { Stapedial } \\
\text { footplate } \\
\text { area }\left(\mathrm{mm}^{2}\right)\end{array}$ & $\begin{array}{l}\text { Ontoge- } \\
\text { netic } \\
\text { stage }\end{array}$ \\
\hline BP/1/4597 & 68.5 & $53.68^{*}$ & 7.68 & 3.26 & 4.24 & 2.31 & $0.65^{\star}$ & 0.35 & - & subadult \\
\hline NMP581 & 68.6 & 45.28 & 6.30 & 2.85 & 3.12 & 1.60 & 0.80 & 0.50 & - & subadult \\
\hline $\begin{array}{l}\text { RC845 } \\
\text { SAM- }\end{array}$ & 69 & 61.36 & 6.32 & 2.35 & 3.11 & 1.27 & 0.53 & 0.35 & - & subadult \\
\hline $\begin{array}{l}\text { PK-K1119 } \\
\text { SAM }\end{array}$ & 72 & 47.95 & 5.83 & 3.07 & 2.45 & 1.60 & 0.82 & 0.41 & 10.16 & subadult \\
\hline PK-K9956 & 73 & 48.59 & 7.50 & 3.01 & 3.56 & 1.60 & 0.86 & 0.55 & - & subadult \\
\hline UMCZ T819 & 85 & - & 8.25 & 3.77 & 2.40 & 1.10 & 1.56 & 1.10 & - & subadult \\
\hline NMQR1451 & 90 & 68.66 & 10.69 & 3.12 & 4.49 & 1.82 & 0.77 & 0.45 & - & adult \\
\hline AMNH2223 & 100 & 74.38 & 14.40 & 4.70 & 3.34 & 1.81 & 1.24 & 1.40 & - & adult \\
\hline NMQR860 & 114 & 90.60 & 14.74 & 6.71 & 7.07 & 4.33 & 1.04 & 1.49 & - & adult \\
\hline
\end{tabular}

TABLE 3. - Geographical and stratigraphical provenance of Thrinaxodon liorhinus Seeley, 1894 and Galesaurus planiceps Owen, 1859 specimens analyzed. All the specimens are from the Karoo Basin in South Africa.

\begin{tabular}{|c|c|c|c|c|c|}
\hline Specimen & Locality & District & Province & Stratigraphic unit & $\begin{array}{l}\text { Assemblage } \\
\text { Zone }\end{array}$ \\
\hline \multicolumn{6}{|c|}{ Thrinaxodon liorhinus } \\
\hline $\begin{array}{l}\text { BP/1/5372 } \\
\text { TM 80a } \\
\text { BP/1/4280 } \\
\text { TM 80b } \\
\text { BP/1/5208 } \\
\text { BP/1/7199 }\end{array}$ & $\begin{array}{l}\text { Donald } 207 \\
\text { Harrismith Commonage } \\
\text { Harrismith Commonage } \\
\text { Harrismith Commonage } \\
\text { Fairfax } \\
\text { Admiralty Estates at } \\
\text { the base of Oliviershoek Pass } \\
\text { Harrismith Commonage } \\
\text { Harrismith Commonage } \\
\text { Harrismith Commonage }\end{array}$ & $\begin{array}{l}\text { Bethulie } \\
\text { Harrismith } \\
\text { Harrismith } \\
\text { Harrismith } \\
\text { Bergville } \\
\text { Bergville } \\
\text { Harrismith } \\
\text { Harrismith } \\
\text { Harrismith }\end{array}$ & $\begin{array}{l}\text { Free State } \\
\text { Free State } \\
\text { Free State } \\
\text { Free State } \\
\text { Kwa-Zulu Natal } \\
\text { Kwa-Zulu Natal } \\
\text { Free State } \\
\text { Free State } \\
\text { Free State }\end{array}$ & $\begin{array}{l}\text { lower Katberg Formation } \\
\text { Harrismith Member, Normandien Formation } \\
\text { Harrismith Member, Normandien Formation } \\
\text { Harrismith Member, Normandien Formation } \\
\text { Harrismith Member, Normandien Formation } \\
\text { Harrismith Member, Normandien Formation } \\
\text { Harrismith Member, Normandien Formation } \\
\text { Harrismith Member, Normandien Formation } \\
\text { Harrismith Member, Normandien Formation }\end{array}$ & $\begin{array}{l}\text { Lystrosaurus AZ } \\
\text { Lystrosaurus AZ } \\
\text { Lystrosaurus AZ } \\
\text { Lystrosaurus AZ } \\
\text { Lystrosaurus AZ }\end{array}$ \\
\hline \multicolumn{6}{|c|}{ Galesaurus planiceps } \\
\hline $\begin{array}{l}\text { BP/1/4597 } \\
\text { RC } 845 \\
\text { SAM-PK-K1119 } \\
\text { SAM PK } 9956 \\
\text { UMCZ T819 } \\
\text { NMQR } 1451 \\
\text { AMNH } 2223 \\
\text { NMQR } 860\end{array}$ & $\begin{array}{l}\text { Donald } 207 \\
\text { Donald } 207 \\
\text { Harrismith commonage } \\
\text { Donald } 207 \\
\text { Harrismith commonage } \\
? \\
\text { Harrismith commonage } \\
\text { Harrismith commonage }\end{array}$ & $\begin{array}{l}\text { Bethulie } \\
\text { Bethulie } \\
\text { Harrismith } \\
\text { Bethulie } \\
\text { Harrismith } \\
\text { Bethulie } \\
\text { Bethulie } \\
\text { Harrismith }\end{array}$ & $\begin{array}{l}\text { Free State } \\
\text { Free State } \\
\text { Free State } \\
\text { Free State } \\
\text { Free State } \\
\text { Free State } \\
\text { Free State } \\
\text { Free State }\end{array}$ & $\begin{array}{l}\text { ? } \\
\text { lower Katberg Formation } \\
\text { Harrismith Member, Normandien Formation } \\
\text { Harrismith Member, Normandien Formation } \\
\text { Harrismith Member, Normandien Formation } \\
? \\
\text { Harrismith Member, Normandien Formation } \\
\text { Harrismith Member, Normandien Formation }\end{array}$ & $\begin{array}{l}\text { Lystrosaurus AZ } \\
\text { Lystrosaurus AZ } \\
\text { Lystrosaurus AZ } \\
\text { Lystrosaurus AZ } \\
\text { Lystrosaurus AZ } \\
\text { Lystrosaurus AZ } \\
\text { Lystrosaurus AZ } \\
\text { Lystrosaurus AZ }\end{array}$ \\
\hline
\end{tabular}

Similar to the early juvenile BP/1/5372 and the subadult TM 80a, the lateral platform is wider than the medial one in $\mathrm{BP} / 1 / 5208$. It is not possible to state if a dorsal process was present.

$\mathrm{BP} / 1 / 7199$ is a complete skeleton not extracted from the concretioned matrix (Fernandez et al. 2013). It was microCT-scanned and thus both stapes were made available. The left stapes is in situ and perfectly preserved (Figs 1G; 4C, D) whereas the right one is displaced and bears some cracks. The stapes is the less elongated among subadult and adult specimens (width/length aspect ratio: 0.58 ) although still more elongated than the early juvenile BP/1/5372. The difference in width between the crura (aspect ratio: 0.31) is among the largest in the sample, comparable to one of the smallest (TM 80a) and one of the largest (TM 81) specimens (Tables 1; 4). The stapedial foramen is not very oval but more rounded (width/ length aspect ratio: 0.74 ), a condition shared with the early juvenile $\mathrm{BP} / 1 / 5372$, the subadult TM $80 \mathrm{a}$, and the adults TM 377 and NMQR 811 and different from the elongated foramen in other specimens. There is a small but conspicuous projection on the anterolateral corner of the bone. The oval foot plate is flat and slightly longer than higher, whereas the contact with the quadrate is comparatively lower and elongated (Fig. 4C, D). A large flange-like dorsal process arises from the posterior crus and the posterior sector of the lateral platform (Figs $1 \mathrm{H}$; 4C).

TM 377 bears a left stapes not preserved in natural position. The stapes is almost complete with only minor damage but the glue and sediment on the fossil make it difficult to properly examine structures of the medial and lateral portions of the bone (Fig. 1I). The anterior crus is relatively wide, with the posterior crus representing $61 \%$ of the width of the anterior one (Tables $1 ; 4)$. The stapedial foramen is among the smallest of the sample, only $31 \%$ of the length of the bone, comparable 
A
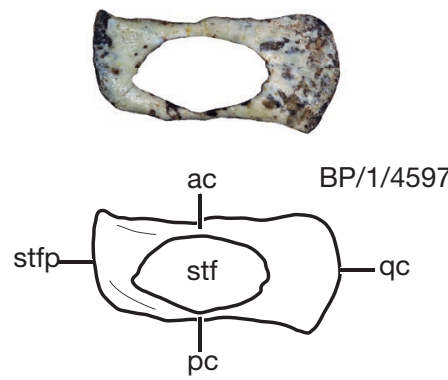

D

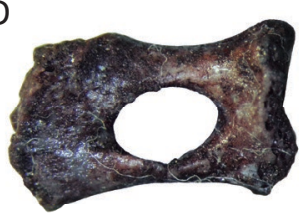

B

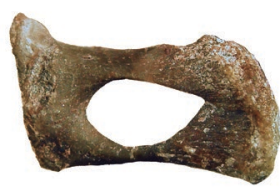

C

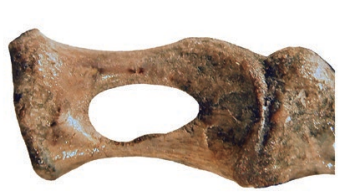

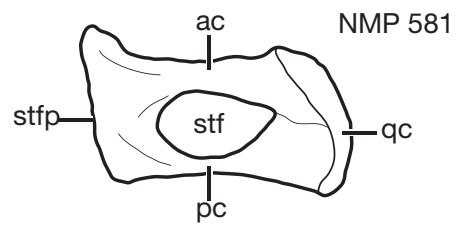

E

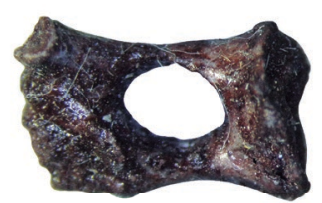

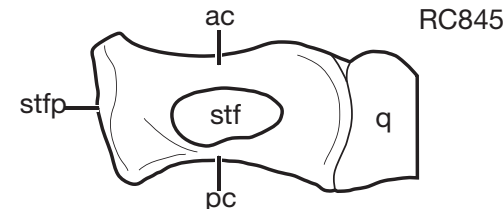

F

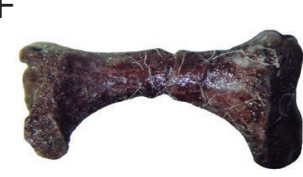

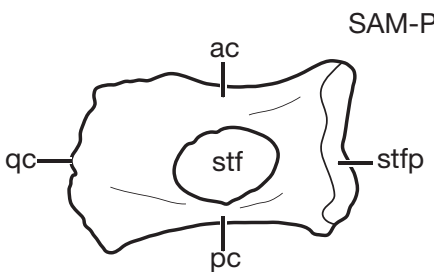

G

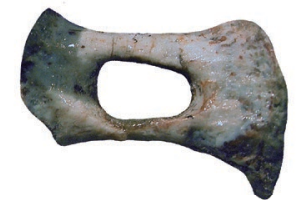

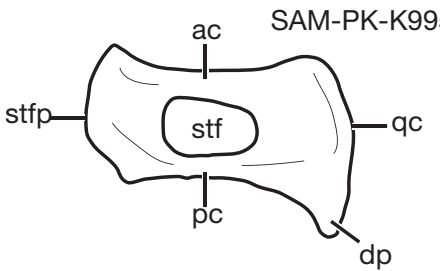

J

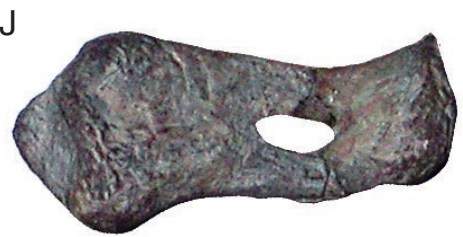

AMNH2223

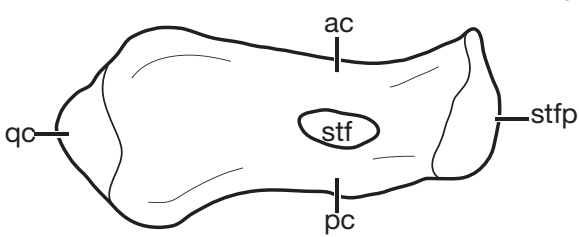

$\mathrm{H}$

SAM-PK-K1119
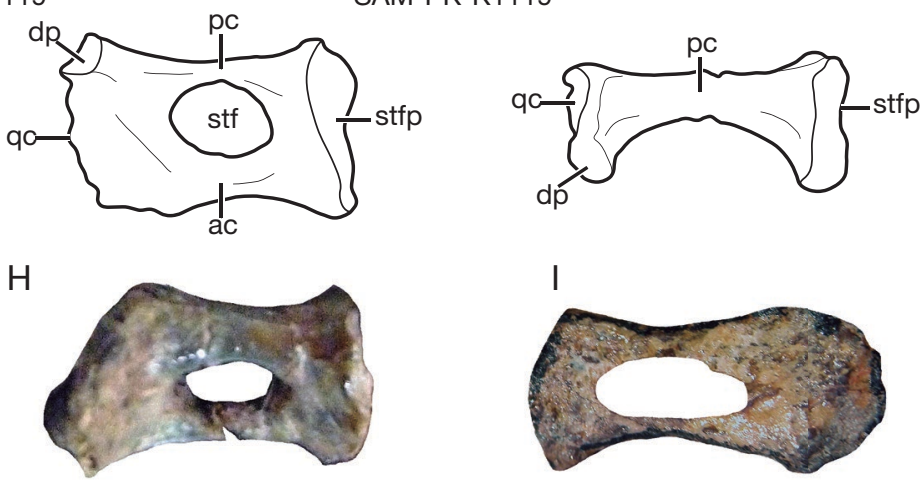

UCMZ T819

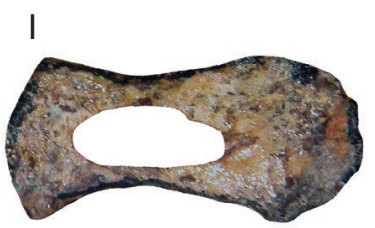

NMQR1451

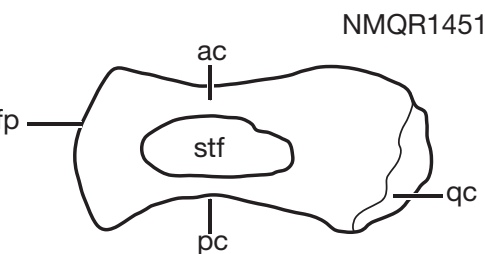

pc

K

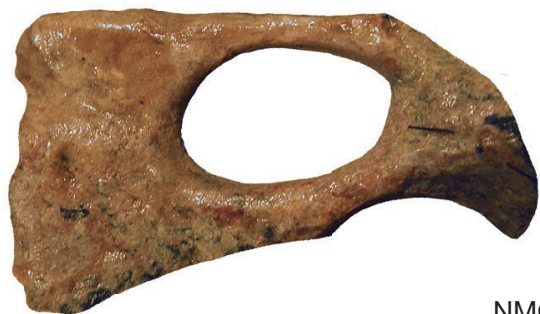

NMQR860

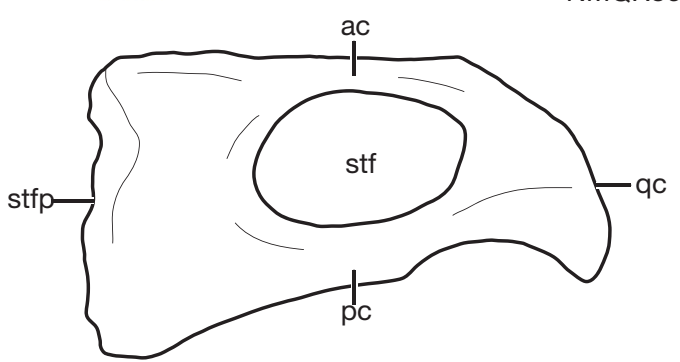

FIG. 2. - Stapes of Galesaurus Owen, 1859: A, left stapes of BP/1/4597 in ventral view; B, left stapes of NMP 581 in ventral view; C, left stapes of RC845 in ventral view; D-F, Right stapes of SAM-PK-K1119; D, ventral; E, dorsal; F, posterior views; G, left stapes of SAM-PK-K9956 in ventral view; H, right stapes of UMCZ T819 in ventral view; I, left stapes of NMQR1451-C1186 in ventral view; J, right stapes of AMNH2223 in ventral view; K, left stapes of NMQR860 in ventral view. Abbreviations: ac, anterior crus; dp, dorsal process; pc, posterior crus; q, quadrate; qc, quadrate contact area; stf, stapedial foramen; stfp, stapedial footplate. Scale bar: $5 \mathrm{~mm}$. 

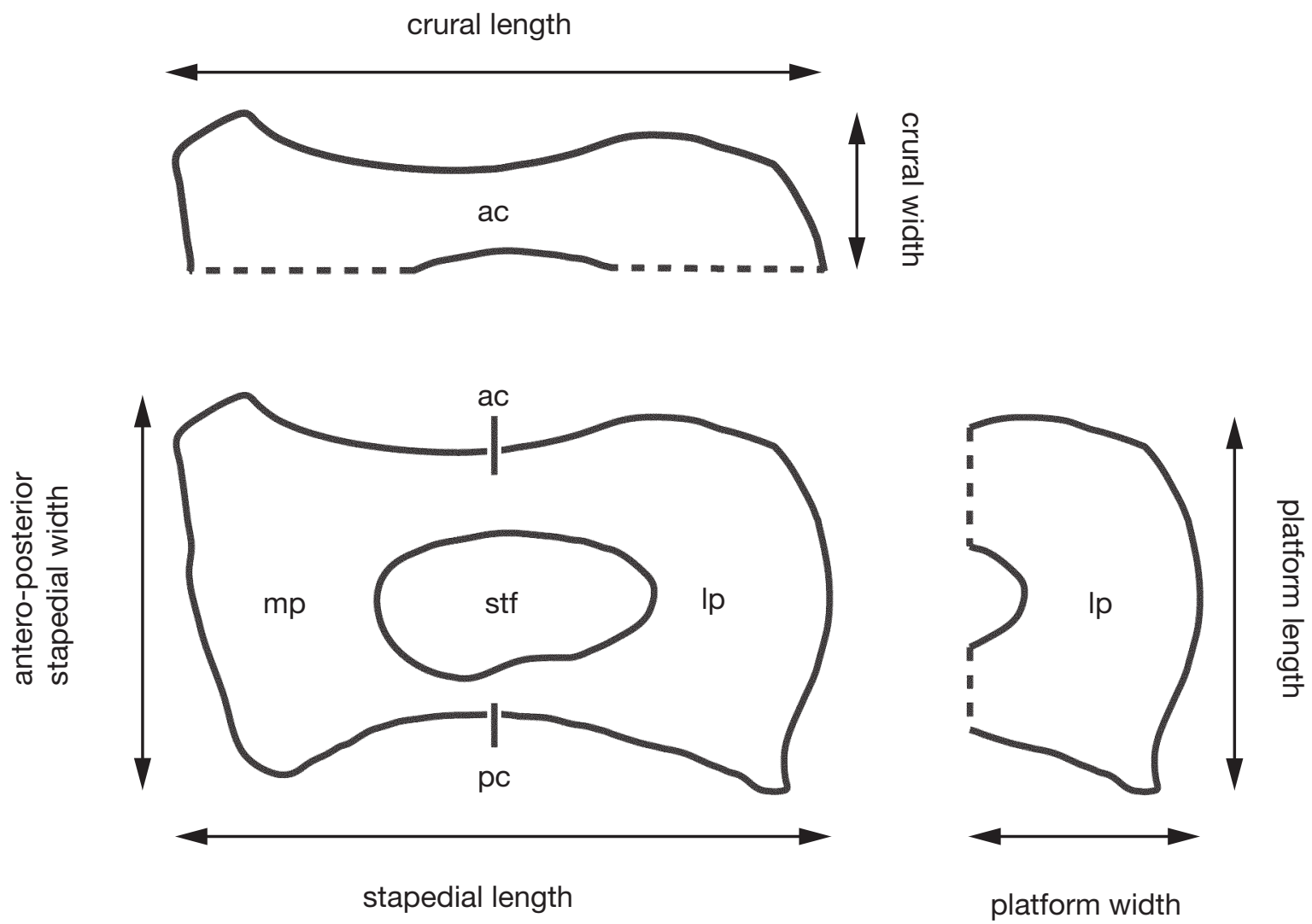

FIG. 3. - Line drawing of a left stapes in ventral view showing the terminology used in the text to refer to the dimensions of different stapedial structures. Abbreviations: ac, anterior crus; Ip, lateral platform; mp, medial platform; pc, posterior crus; stf, stapedial foramen.

to the relative size of the foramen in the subadult specimen TM 80a. In addition, the stapedial foramen is quite circular with a width/length aspect ratio of 0.85 . A dorsal process is not clearly observed but hinted.

NMQR 811 is a fragmented skull with the well-preserved left stapes (Figs 1J; 4C, D) close to its original position, as it is still in contact with the fenestra ovalis medially. The stapes of NMQR 811 is notably short when compared to that of TM 81, which has a similar basal skull length. It is a slender bone (the width/length aspect ratio is only 0.42 ) with a small stapedial foramen, approximately at $35 \%$ of the length of the stapes (Tables $1 ; 4$ ). The stapedial foramen is oval but not very elongated, comparable in shape with that of the early juvenile specimen $\mathrm{BP} / 1 / 5372$. The medial platform is slightly wider than the lateral platform. These platforms are mostly composed by the contribution from the anterior crus, specially the lateral one in which there is a crest representing the limit between the crura. The footplate is convex and circular whereas the anteroposteriorly elongated lateral contact with the quadrate is nearly rectangular (Fig. 4E, F). The well-developed and robust dorsal process is triangular and projected dorsally with a slight posterior orientation.

The right stapes of TM 81 is only slightly displaced and almost non-deformed but its lateral portion is not well-preserved
(Fig. $1 \mathrm{~K}$ ). The posterior crus is very slender, representing $28 \%$ of the width of the anterior crus (Tables 1; 4). Opposite to NMQR 811, the lateral platform is wider than the medial one. The medial platform is only represented by the fussed crura (Fig. 1K) that can be recognized due to the presence of a crest that sets the crura apart and represents the suture between them. A robust and triangular dorsal process pointing dorsomedially and posteriorly, similar to that in NMQR 811, can be observed emerging from the lateral platform posterior portion (Fig. 1K).

The stapes of BP/1/1375 is only slightly larger than TM 81 (Table 1). The right stapes is almost complete with only the shaft of the posterior crus missing (Fig. 1L) whereas the left stapes is more fragmentary. Unlike TM 81, the lateral and medial platforms are similarly lateromedially developed, and the anterolateral corner of the stapes is projected anteriorly. The presence of a dorsal process cannot be asserted.

\section{GALESAURUS}

The stapes of Galesaurus show notable variation in characters among the available specimens. Thus it may not be accurate to generalize several characters of its stapes. The stapes is rectangular with an oval stapedial foramen and two crura that meet laterally and medially to form platforms. The stapedial 

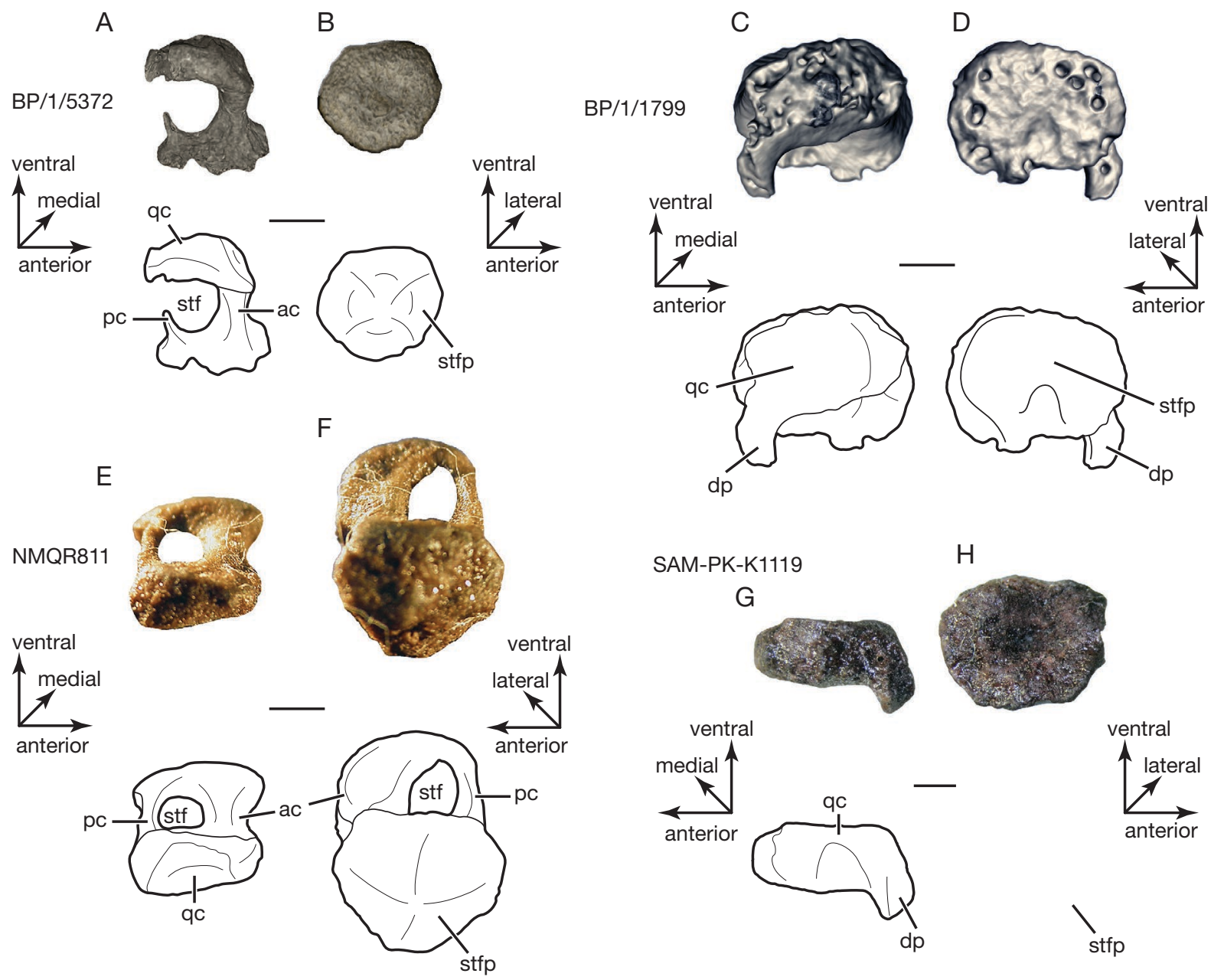

$\mathrm{H}$
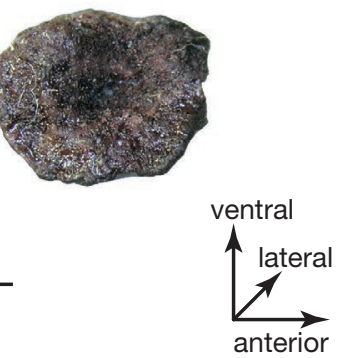

FIG. 4. - A-F, Stapes of Thrinaxodon Seeley, 1894; G, H, Galesaurus Owen, 1859. A, left stapes of BP/1/5372 in dorsolateral view; B, right stapes of BP/1/5372 in medial view; C, D, left stapes of BP/1/7199; C, lateral; D, medial views; E, F, left stapes of NMQR811; E, ventrolateral; F, ventromedial views; G, H, right stapes of SAM-PK-K1119; G, lateral; H, medial views. Abbreviations: ac, anterior crus; dp, dorsal process; pc, posterior crus; q, quadrate; qc, quadrate contact area; stf, stapedial foramen; stfp, stapedial footplate. Scale bars: $1 \mathrm{~mm}$

foramen is approximately half the length of the stapes in most of the specimens except in one, in which it is relatively small. In the two largest specimens the posterior crus is anteroposteriorly wider than the anterior one whereas the opposite is observed in the remaining, smaller specimens. The development of the platforms is variable among the specimens. Furthermore, there is variation in the relative width of the platforms when comparing the lateral and the medial one of the same specimen. The stapes bears a posterolateral and antero and posteromedial projections whereas the anterolateral region is well-rounded. A dorsal process is present but its morphology is variable, being alternatively flat and delicate or cylindrical and robust in different specimens.

Both stapes of BP/1/4597 are in situ and can be observed in ventral view. The left element is almost complete (Fig. 2A). Although some breakage is recognized on the posterior crus, it appears that the crura are more slender than in other specimens. The stapes is rectangular and is pierced by an elongated stapedial foramen. The foramen occupies slightly more than half the length of the stapes. BP/1/4597 has the largest foramen relative to the whole bone, among the specimens of our study sample (Tables $2 ; 4$ ). The lateral platform is wider than the medial one. The presence of a dorsal process cannot be ascertained.

NMP 581 has the same skull size than BP/1/4597 (Table 2). Stapes from both sides are well-preserved and only slightly displaced from their original position. They are only observable in ventral view (Fig. $2 \mathrm{~B}$ ). The stapes is elongated as in $\mathrm{BP} / 1 / 4597$, being its width $45 \%$ of its length, and bears a similarly shaped stapedial foramen (Tables $2 ; 4$ ). The crura are relatively wider as in larger specimens. Unlike what is observed in $\mathrm{BP} / 1 / 4597$, the medial and lateral platforms are subequal in width, both relatively narrow when compared to other specimens. The suture line between the crura is visible on the platforms. It is not possible to observe if the dorsal process is present.

RC 845 skull is nearly the same size than $\mathrm{BP} / 1 / 4597$ and NMP 581 (Table 2). In RC 845, both well-preserved stapes are 
TABLE 4. - Selected ratios between skull and stapedial measurements of the analysed specimens of Thrinaxodon Seeley, 1894 and Galesaurus Owen, 1859.

\begin{tabular}{|c|c|c|c|c|}
\hline Specimen & $\begin{array}{l}\text { Anteroposterior to } \\
\text { lateromedial stapes ratio }\end{array}$ & $\begin{array}{l}\text { Anteroposterior to } \\
\text { lateromedial foramen } \\
\text { ratio }\end{array}$ & $\begin{array}{l}\text { Foramen to stapes } \\
\text { lateromedial length }\end{array}$ & $\begin{array}{l}\text { Posterior to anterior } \\
\text { crus ratio }\end{array}$ \\
\hline \multicolumn{5}{|l|}{ Thrinaxodon } \\
\hline BP/1/5372 & 0.73 & 0.67 & 0.62 & 0.44 \\
\hline TM 80a & 0.5 & 1.01 & 0.3 & 0.29 \\
\hline $\mathrm{BP} / 1 / 4280$ & 0.46 & 0.38 & 0.46 & 0.37 \\
\hline TM 80b & 0.4 & 0.42 & 0.48 & 0.71 \\
\hline TM 782 & 0.42 & 0.45 & 0.55 & 0.39 \\
\hline $\mathrm{BP} / 1 / 5208$ & 0.52 & 0.59 & 0.51 & 0.58 \\
\hline $\mathrm{BP} / 1 / 7199$ & 0.58 & 0.74 & 0.49 & 0.31 \\
\hline TM 377 & 0.5 & 0.85 & 0.31 & 0.61 \\
\hline NMQR811 & 0.42 & 0.69 & 0.35 & 0.52 \\
\hline TM 81 & 0.43 & 0.45 & 0.55 & 0.28 \\
\hline $\mathrm{BP} / 1 / 1375$ & 0.43 & 0.44 & 0.53 & $0.47^{*}$ \\
\hline \multicolumn{5}{|l|}{ Galesaurus } \\
\hline $\mathrm{BP} / 1 / 4597$ & 0.42 & 0.54 & 0.55 & $0.54^{*}$ \\
\hline NMP581 & 0.45 & 0.51 & 0.5 & 0.63 \\
\hline RC845 & 0.37 & 0.41 & 0.49 & 0.66 \\
\hline SAM-PK-K1119 & 0.53 & 0.65 & 0.42 & 0.5 \\
\hline SAM PK-K9956 & 0.4 & 0.45 & 0.47 & 0.64 \\
\hline UMCZ T819 & 0.46 & 0.46 & 0.29 & 0.71 \\
\hline NMQR1451 & 0.29 & 0.41 & 0.42 & 0.58 \\
\hline AMNH2223 & 0.33 & 0.54 & 0.23 & 1.13 \\
\hline NMQR860 & 0.46 & 0.61 & 0.48 & 1.43 \\
\hline
\end{tabular}

only slightly rotated from their original placement. The stapes of RC 845 (Fig. 2C) is more elongated than that of $\mathrm{BP} / 1 / 4597$ and NMP 581 as the width of the bone represents $37 \%$ of its length (Tables 2; 4). Similar to NMP 581, the stapedial foramen is approximately half of the total length of the stapes. Together with the adult specimen NMQR 1451, the stapedial foramen in RC 845 is one of the most elongated (width/length aspect ratio is 0.41 ). Medially, the ventral surface of the anterior crus is flat whereas that of the posterior one is inflated. In addition, the medial portion of the posterior crus presents an anterior and a posterior broad crest that define a central concave region. Hence, the individuality of the crura is clearly recognizable. The lateral platform is ventrally flat and there is no trace of each individual crus. As in NMP 581, the medial and lateral platforms are almost the same width in RC 845. The convex lateral margin of the stapes contacts the medial region of the quadrate (Fig. 2C). Both elements are only separated by a thin matrix layer. A small, flat, triangular dorsal process is present on the posterolateral region of the stapes.

The right stapes of SAM-PK-K1119 is well-preserved and has been fully acid-prepared and separated from the skull (Figs 2D, F; 4G, H). This is the stouter stapes of Galesaurus, in which the width represents $53 \%$ of the length of the bone (Tables 2; 4). The stapedial foramen of SAM-PK-K1119 is the roundest among the specimens of Galesaurus, with a width/length aspect ratio of 0.65 . Ventrally, both the lateral and the medial platforms are concave, especially in the central portion. The lateral platform is more than twice the width of the medial one. There is some damage in the dorsal surface of the lateral platform. Additionally, the lateral surface of the stapes seems to lack periosteal surface. In medial aspect, the stapedial footplate is concave and oval, with the long axis anteroposteriorly oriented (Fig. 4H). In lateral view, the stapes is rectangular, being anteroposteriorly wider than dorsoventrally high (Fig. 4G). A well-developed, robust, cylindrical dorsal process projects dorsally from the posterolateral corner of the stapes (Figs 2E, F; 4G).

The left stapes of SAM-PK-K9956 seems undistorted and well-preserved (Fig. 2G) whereas the right one is deformed and damaged, especially laterally. There are well-developed medial and lateral platforms, with the lateral one wider than the medial one, although the width difference between the platforms is smaller than in SAM-PK-K1119. The dorsal process is a flat projection emerging from the posterior crus that reminds the process of RC 845 but is notably different from the robust process of SAM-PK-K1119.

UMCZ T819 preserves the right stapes, rotated from its original position but showing no evident deformation (Fig. $2 \mathrm{H}$ ). The stapes is more robustly constructed than those of other Galesaurus specimens analysed (Fig. 2H); however, the relative proportions are similar to other specimens. It is a rectangular element (the width/length aspect ratio is 0.46 ; Tables 2 ; 4). The stapedial foramen is among the smallest of the sample, representing $29 \%$ of the total length of the bone. As in other specimens, the foramen is ellipsoidal, approximately twice as long as wide. The posterior crus is comparatively wide, being $71 \%$ of the anterior one. The medial platform is relatively narrow, representing half the width of the lateral platform as in the smallest specimen of the sample (BP/1/4597), in the only slightly smaller SAM-PK-K1119, and in the adult specimen NMQR 1451. The presence of a dorsal process cannot be ascertained.

NMQR 1451 is a poorly preserved left stapes located almost in life-position (Fig. 2I). This is the most slender stapes of 
Galesaurus sample. The stapedial width is only $29 \%$ of its length (Tables 2; 4). The medium-sized stapedial foramen has a length at $42 \%$ of the length of the bone. The foramen of this specimen is among the most elongated of the sample. The medial platform is relatively narrow, representing half the width of the lateral one. The platforms are flat and there are no visible sutures between the fused crura. A dorsal process cannot be observed.

AMNH 2223 right stapes has been separated from the skull allowing its complete observation. The stapes of specimen AMNH 2223 is notoriously different than those of other Galesaurus specimens (Fig. 2J). In fact, this stapes appears as a morphologic outlier of those of known non-mammaliaform cynodonts and might represent a pathologic condition. The bone is very slender, the width of the stapes being only $33 \%$ of the length of the bone (Tables 2; 4). Strikingly, the posterior crus is wider than the anterior one (with a 1.13 aspect ratio), a condition only shared by the largest specimen (NMQR 860). The oval stapedial foramen is remarkable small in comparison with all the other specimens analysed (Fig. 2J), representing only $23 \%$ of the length of the stapes. The lateral platform is massive and large, approximately 2.2 times wider than the medial one. The ventral surface of both platforms is slightly concave. A concavity is also present on the dorsal surface of the lateral platform. The stapedial footplate is relatively small, longer anteroposteriorly than dorsoventrally. Nevertheless, the stapedial footplate is projected ventrally relative to the ventral surface of the medial plate. A dorsal process is apparently absent.

The left stapes of NMQR 860 is not well-preserved and somewhat distorted, but close to its original position (Fig. $2 \mathrm{~K}$ ). The stapes is remarkably wide, especially when compared to AMNH 2223 which is similar in length but only $70 \%$ of its width (Tables 2; 4). The width of the stapes is $46 \%$ of the length. NMQR 860 shares with AMNH 2223 the presence of a posterior crus wider than the anterior one. However, in NMQR 860, the relative width difference between the crura is more marked, being the posterior/anterior width aspect ratio 1.43. Together with SAM-PK-K1119, the stapedial foramen of NMQR 860 is one of the less elongated, being its width $61 \%$ of its length. The medial and lateral platforms are not well-preserved. A dorsal process is not recognized but this could be due to incomplete preservation.

\section{DISCUSSION}

The stapes of Thrinaxodon and Galesaurus specimens analysed share general morphological traits which are also recognized in other non-mammaliaform cynodonts. Nevertheless, several differences regarding the shape, proportions, and relative development of various features are recorded between the studied individuals (Figs 1; 2; 4; Tables 1; 2; 4). In addition, various specimens of Thrinaxodon suggest that the stapes-quadrate articulation is restricted to the centrum-to-posterior portion of the lateral margin of the stapes (Fig. 1G), whereas in Galesaurus the contact with the quadrate is along the complete lateral margin of the stapes (Fig. 2C).
We explored the behaviour of some measurements in our sample to interpret allometric trends in the stapes, using BSL as a proxy to the overall size and an independent variable. The lateromedial length of the stapes in Galesaurus has a statistically significant positive allometry which is also the case for the anteroposterior width of the stapes, although the latter is statistically significant only under RMA method (Table 5). In Thrinaxodon, the values of the coefficients for the lateromedial length are also above 1 but they are not significantly different from 1 (isometry). However, the anteroposterior width of the stapes is strongly negative, and the growth model is therefore different to that of Galesaurus (Fig. 5). In non-mammaliaform cynodonts the length of the stapes is conditioned by the distance between the quadrate and the fenestra ovalis (Wible 1991), which is expected to increase with the size of the skulls and, consequently, with ontogeny. Using the skull width at the level of the quadrates as a proxy to the quadrate-fenestra ovalis distance, we analysed the stapedial length to skull width ratio. We found that these measurements are poorly correlated in Thrinaxodon $\left(\mathrm{R}^{2}=0.5\right)$ but a good correlation was found in Galesaurus $\left(\mathrm{R}^{2}=0.8\right)$. Variation in the allometry coefficient between the species is more or less comparable to that obtained using BSL being the value of the coefficient also more pronounced for Galesaurus than Thrinaxodon ( 1.52 vs 1.27 under RMA; 1.36 vs 0.96 under LS) but the results were not statistically significant for these variables. It is not possible to compare our results with those commonly proposed for the allometric ontogeny of the middle ear system in mammals (e.g. Luo 2011; Ramírez-Chaves et al. 2016). This is because those models are considering variations (and detachment of the Meckelian cartilage) of the malleus, incus, and ectotympanic bones but not ontogenetic changes of the stapes.

Rowe (1988) introduced the relative length of the stapes in relation to the skull length as a phylogenetic character and Wible (1991; see also Wible \& Hopson 1993) quantitatively defined the states for this character. He distinguished between taxa in which the stapes was longer than $7.5 \%$ and those in which it represented less than $5.5 \%$ of the total length of the skull. Furthermore, Wible (1991) recovered the latter state as an unequivocal synapomorphy of Mammaliaformes (sensu Rowe 1988), a clade including Sinoconodon Patterson \& Olson 1961, Morganucodontidae, their most recent common ancestor, and all its descendants ("node 3" of Wible \& Hopson 1993). Wible (1991; see also Meng 1992) also stated a third state of character, variation from $0.05 \%$ to $4.2 \%$ of the total length of the skull, for recent mammals, which give a clear idea of the enormous size difference between this element in any non-mammaliaform cynodont and living mammals. Percentual values estimated more recently for the haramiyid Arboroharamiya Zheng et al., 2013 is 4\% (Meng et al. 2018). Our observations show that the stapes to skull length aspect ratio is 6-9\% in Thrinaxodon, 8-13\% in Galesaurus, 13\% in the basal epicynodont Vetusodon (see Abdala et al. 2019), and 7-13\% in gomphodont cynodonts (Gaetano \& Abdala 2015). Therefore, the stapes of non-mammaliaform cynodonts 

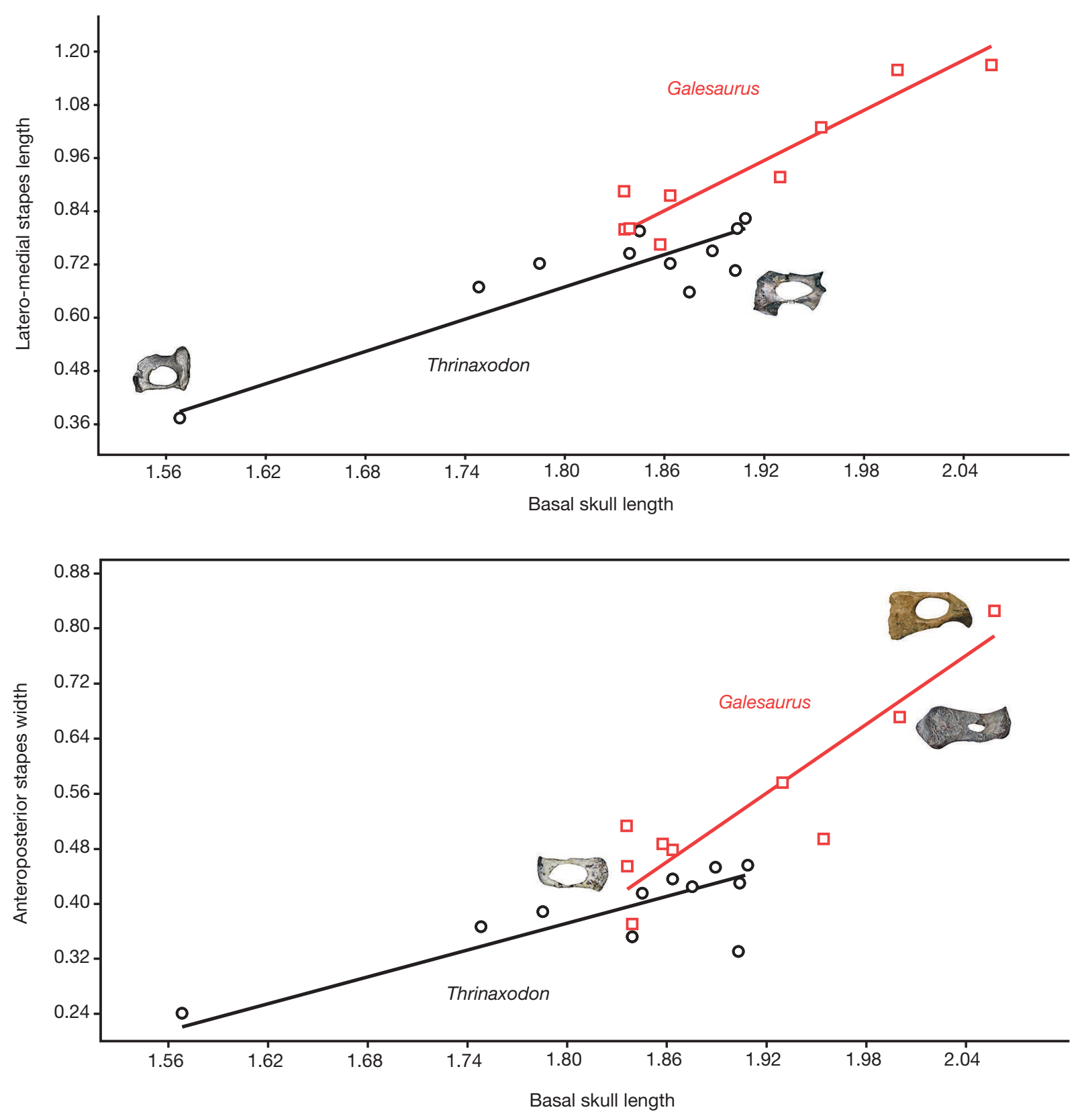

FIG. 5. - Bivariate plot under Reduced Major Axis method of log transformed values of basal skull length against the lateromedial stapedial length (above) and the basal skull length against the anteroposterior stapes width (below). Black circles and lines indicate specimens and slopes for Thrinaxodon Seeley, 1894; red squares and lines indicate specimens and slopes for Galesaurus Owen, 1859. Inset figures show smallest and largest representatives of the stapes of Thrinaxodon (above) and Galesaurus (below).

appear to range between $6 \%$ and $13 \%$ of the skull length. The present knowledge of non-mammaliaform cynodont stapes therefore indicates that $6 \%$ should be the lower boundary for this character state.

There is a wide variation in the stapes morphology (width/ length ratio) of Thrinaxodon, but the smallest specimens (BP/1/5372 and UCMP 42878; Estes 1961: Fig. 2) feature a squarish, more robust stapes (width at $73 \%$ of the length in $\mathrm{BP} / 1 / 5372$ ), suggesting that this morphology is a juvenile condition. In Galesaurus the smallest stapes recorded is already rectangular (the width $42 \%$ of the length) and there is no record of a quadrangular pattern like that of the Thrinaxodon juvenile.

Other measurements show a wide range of intraspecific variation that cannot be explained by ontogeny. For example, there is a wide variation in the length of the stapedial foramen in these cynodonts but more marked in Thrinaxodon (Fig. 6) that does not seem to be related to ontogeny. In addition, the stapedial foramen is usually ovoid to ellipsoid as is the case in most non-mammaliaform cynodonts (e.g. Gaetano \& Abdala 2015, 2017), but there are two Thrinaxodon specimens of different sizes with a circular to near circular foramen 
(Fig. 1B, I). Disparity in the size of the stapedial foramen has been reported as specific variations for the mole rat Spalax Güldenstaedt, 1770 (Mason et al. 2010: Fig. 2) and the golden mole Chrysochloris Lacépède, 1799 (Mason 2003: Fig. 6A, B). Individual variation including presence/absence of a narrow stapedial foramen was reported in the sloths Bradypus Linnaeus, 1758 and Choloephus Illiger, 1811 (Doran 1878: 471, 472). It is also interesting to note ontogenetic changes in the foramen of the colugo Cynocephalus Boddaert, 1768 with juveniles featuring a large stapedial foramen that in adults is filled by a lamina (Doran 1878).

Considering the development of the crura, Thrinaxodon invariably shows a wider anterior crus (Table 1), which is the condition observed in other non-mammaliaform cynodonts. The width of the crura was most similar (posterior/anterior crus width aspect ratio is 0.71 ) in the middle-sized specimen TM 80b whereas the greatest width difference (aspect ratio is 0.28 ) is found in one of the largest specimens (TM 81) (Table 4). The only cases in which the posterior crus is wider are in the two largest specimens of Galesaurus (AMNH2223 and NMQR860) (Tables 2; 4). Data on variation of middle ear bones, including stapes, in recent mammals are best explored and illustrated, in our knowledge, by Doran (1878). Next, differences in the stapes reported for the same species and for closely related taxa are highlighted. Variation in the size of the crura is known in humans, where usually the anterior crus is slender, but there are cases where it is difficult to discriminate the anterior from the posterior crus (Doran 1878). In addition, considering anomalies of the middle ear bones in humans, it is clear that the stapes is frequently modified. Thus Park \& Choung (2009) reported 21 patterns of congenital ossicular anomalies, 16 of them affecting the stapes, mostly in changes of morphology and fixation of the plate. In different species of Canis Linnaeus, 1758 the crura could be more curved or straight (Doran 1878). Clear differences in the crura are also represented in the African elephant Loxodonta africana Blumenbach, 1797 which shows straight divergent crura and the Indian elephant Elephas maximus Linnaeus, 1758 showing a curved posterior crus but a straight anterior one (Doran 1878). Deep ontogenetic changes are also observed in the stapes of some artiodactyls such as Ovis aries Linnaeus, 1758, Bos taurus Linnaeus, 1758 and Giraffa Brisson, 1762 which show much lighter and triangular stapes with more divergent crura at birth and more robust, quadrangular stapes with small or non-divergent crura in adults (Doran 1878: plate 61, figures 14-17). Variation with zebu (Bos taurus indicus Linnaeus, 1758) is also reported, with this subspecies showing more slender ear bones and the stapes "more oblong" than in B. taurus (see Doran 1878: 427). The outline morphology of the bone in adult Bos Linnaeus, 1758 resembles that of non-mammaliaform cynodonts (more particularly those in young Thrinaxodon) as the crura are subparallel and the bone is squarish (width $68 \%$ of the length).

The stapedial footplate area-to-basal skull length aspect ratio is close in the three specimens of Thrinaxodon in which this proportion can be examined (Table 1), as well as the one specimen presented by Laaß (2016), varying from 7\%
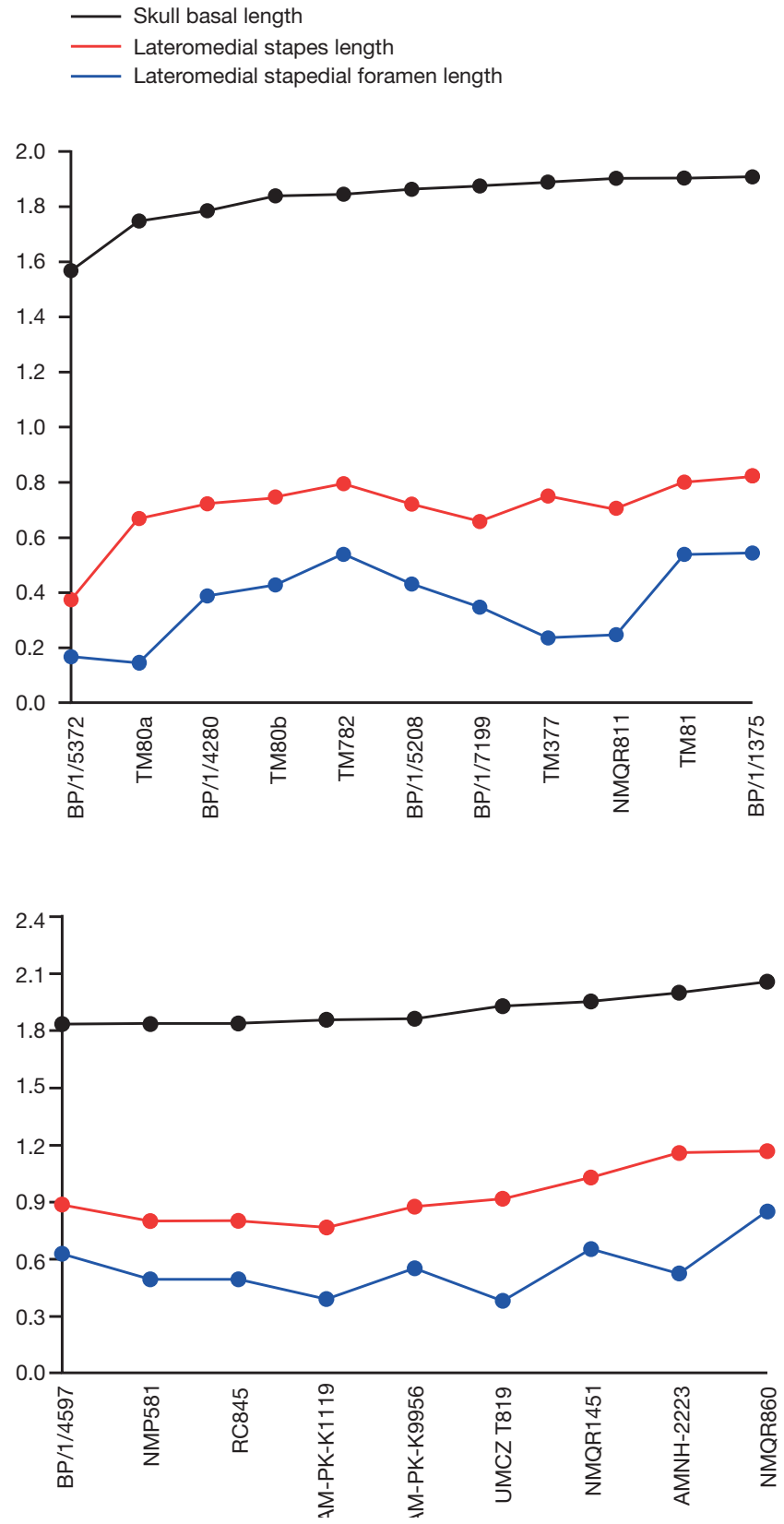

FIG. 6. - Graph showing variation of log-transformed basal skull length (black), lateromedial stapes length (red), and lateromedial stapedial foramen length (blue), from the smallest to largest specimens for Thrinaxodon Seeley, 1894 (above) and Galesaurus Owen, 1859 (below).

to $9 \%$, the higher percentage represented in the youngest specimen. In the only Galesaurus specimen in which the stapedial footplate area could be measured (Table 2), the aspect ratio is higher than in Thrinaxodon (0.14). We added our new data to those provided by Laaß (2016). The cluster of Thrinaxodon specimens are placed near Massetognathus Romer, 1967, whereas the closest specimen regarding Galesaurus is the dicynodont Pristerodon Huxley, 1868 (Fig. 7). As mentioned previously by Laaß (2016) there seems to be a remarkably difference in footplate stapes areas between small dicynodonts and cynodonts. In fact, this seems to 
TABLE 5. - Regressions of stapes variables on basal skull length. Abbreviations: $\mathbf{b}_{\mathrm{LS}}$, coefficient of allometry calculated via least squares; $\mathbf{b}_{\mathrm{RMA}}$, coefficient of allometry calculated via reduced major axis method; $\mathbf{n}$, sample size; $\mathbf{R}^{2}$, adjusted coefficient of determination. $\mathbf{P}(\mathbf{a}=\mathbf{1})$ indicates if the values obtained indicate departure from isometry $(b=1)$ and is only reported when there is statistically significant departure from 1 .

\begin{tabular}{|c|c|c|c|c|c|c|c|}
\hline Variable & $\mathbf{n}$ & $\mathbf{R}^{2}$ & $b_{\text {RMA }}$ & $P(a=1)$ & $b_{\text {LS }}$ & $P(a=1)$ & Trend \\
\hline \multicolumn{8}{|l|}{ Thrinaxodon } \\
\hline $\begin{array}{l}\text { Stapes length } \\
\text { Stapes width }\end{array}$ & $\begin{array}{l}11 \\
11 \\
\end{array}$ & $\begin{array}{l}0.78 \\
0.63 \\
\end{array}$ & $\begin{array}{l}1.21 \\
0.64 \\
\end{array}$ & 0.02 & $\begin{array}{l}1.07 \\
0.51\end{array}$ & $\overline{0.004}$ & $\stackrel{-}{\text { Negative }}$ \\
\hline \multicolumn{8}{|l|}{ Galesaurus } \\
\hline $\begin{array}{l}\text { Stapes length } \\
\text { Stapes width }\end{array}$ & $\begin{array}{l}9 \\
9 \\
\end{array}$ & $\begin{array}{l}0.89 \\
0.8 \\
\end{array}$ & $\begin{array}{l}1.87 \\
1.66 \\
\end{array}$ & $\begin{array}{l}0.008 \\
0.05\end{array}$ & $\begin{array}{l}1.76 \\
1.49 \\
\end{array}$ & $\begin{array}{c}0.01 \\
- \\
\end{array}$ & $\begin{array}{l}\text { Positive } \\
\text { Positive }\end{array}$ \\
\hline
\end{tabular}

be a particular condition of the two smallest dicynodonts Kawingasaurus Cox, 1972 and Cistecephalus Owen, 1876, the only two taxa recognized as completely fossorial by Laaß (2016). Similar sized cynodonts such as Brasilodon Bonaparte et al., 2003, Yunanodon (Cui, 1976) and the juvenile Thrinaxodon as well as the basal anomodont Suminia Ivakhnenko, 1994 clearly present a comparatively reduced footplate area of the stapes. Based in the current data in therapsids as presented in Figure 7, it is difficult to correlate a large footplate area with fossoriality, a condition found in golden moles and fossorial rodents (Mason 2001), as in cynodonts assumed to be fossorial or semifossorial such as Galesaurus and Thrinaxodon the area of the footplate is not particularly large. Eventually a phylogenetic signal could be represented in this trait as it seems clear that dicynodonts tends to have comparative larger footplates (all of them are represented above the regression line).

Extant mammals show a number of features of the auditory system that distinguish them from other vertebrates (see Puria \& Steele 2010), including: three middle-ear bones (Masterton et al. 1969; Colbert \& Morales 1991), the presence of distinct radial and circunferential collagen fiber layers of the tympanic membrane (Linn 1968; Funnell \& Laszlo 1982; Rabbitt \& Holmes 1986; Fay et al. 2006), the elongation of the basilar membrane (Manley 1971), and the mobility of the organ of Corti outer hair cells (Brownell et al. 1985). Among others, these characteristics contribute to the unique capability of mammals to perceive high-frequency sounds. Strikingly, only little attention has been paid to the role of middle-ear bones in the hearing of high-frequency sounds (Taylor 1969; Puria \& Steele 2010). Historically, the tri-ossicular condition of the mammalian middle ear has been considered as an amplification system more efficient than that of other tetrapods, which only have a single middle ear bone (Taylor 1969; Masterton et al. 1969). However, the three impedance matching mechanisms in the tri-ossicular middle ear (i.e., ratio between the area of the tympanic membrane and the stapedial footplate; ratio between the lever arms of incus and malleus; the curved tympanic membrane lever system) are also present in mono-ossicular middle ears (Manley 1972; Manley \& Sienknecht 2013). In fact, the only difference between tri-ossicular and monoossicular middle ears is the primary lever system present in mammals compared to the secondary lever system along the extracolumella-columella complex present in other tetrapods (Manley \& Sienknecht 2013).

The lower jaw, the quadrate, and the stapes are interpreted to have been involved in the transmission of sound waves to the internal ear in synapsids (Tumarkin 1955, 1968; Allin 1975; Kermack \& Mussett 1983; Kermack \& Kermack 1984; Allin \& Hopson 1992; Luo \& Crompton 1994; Laaß 2014). In the most basal forms, the stapes is a robust element that participates in the structural support of the braincase. The stapes of these basal synapsids would have acted as an inertial system (Manley 1973; Laaß 2014). The skull vibration due to low frequency substrate vibrations would have been accompanied by a delay in the stapes movement. The difference in vibration timing between the stapes and the rest of the skull would have stimulated the inner ear (Laaß 2014). Along the synapsid lineage, the stapes shows a stepwise reduction of its structural function, gradually becoming a more gracile, horizontally oriented element that would eventually have been capable of vibrating and transmitting those vibrations to the inner ear (Lombard \& Bolt 1979; Allin \& Hopson 1992; Clack 2002; Maier \& van den Heever 2002; Laaß 2016). However, it is not clear in which moment of synapsid evolution the stapes became sensitive to air transmitted sounds, particularly because the soft tissues associated to the hearing capabilities do not fossilize and it is difficult to determine the acoustic properties of the involved elements in fossils (Laaß 2014). Kemp (2007) analyzed several nonmammalian cynodonts and concluded that the postdentary elements and the quadrate would have been able to conduct airborne sound waves only if certain conditions regarding acoustic isolation and links were fulfilled. In addition, the mass and flexibility of the bones involved in sound transmitting must be in certain range and a sound impedance matching system between the tympanic membrane and the oval window must be present. At this stage it is important to borne in mind the fact that there is not a single living tetrapod with an analogue hearing system in fossil synapsids, a lineage where all the putative elements interpreted as involved in sound transmission, stapes, quadrate and postdentary bones, are an order of magnitude larger and probably denser than in living forms. According to Kemp (2007), the physical properties of the elements involved in the audition of non-mammaliaform cynodonts (i.e., tympanic membrane, postdentary bones, quadrate, stapes) would have only allowed 


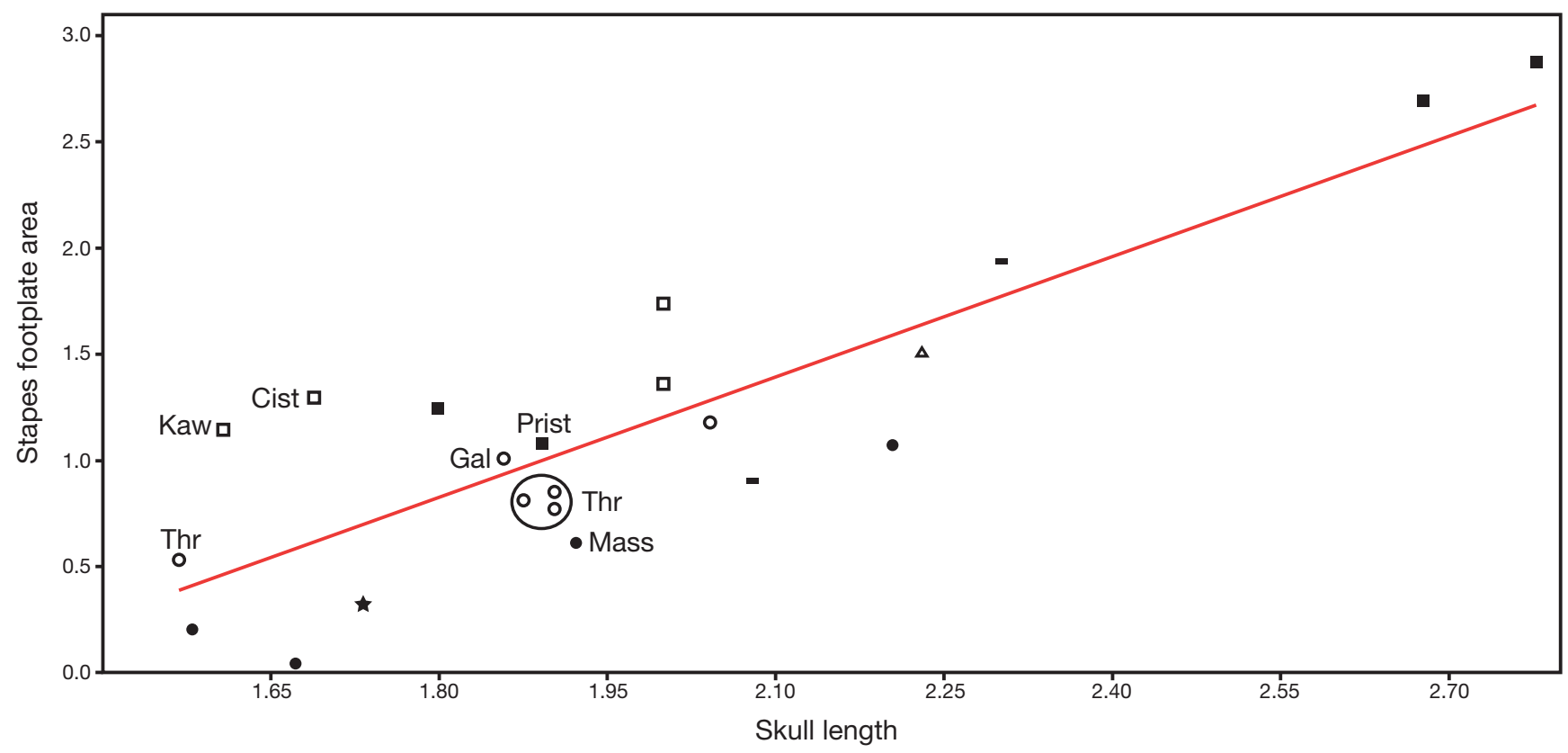

FIG. 7. - Bivariate plot under Least Square method of log transformed values of skull length against the stapedial footplate area. Circles are non-mammaliaform cynodonts, open circles are semifossorial and fossorial non-mammaliaform cynodonts; squares are dicynodonts, open squares are semifossorial and fossorial dicynodonts; star is a basal anomodont; dash lines are therocephalians; triangle is a gorgonopsian. Abbreviations: Cis, Cistecephalus; Gal, Galesaurus; Kaw, Kawingasaurus; Mass, Massetognathus; Pris, Pristerodon; Thr, Thrinaxodon. Data from Laaß (2016) and new values for Thrinaxodon Seeley, 1894 and Galesaurus Owen, 1859 (see Tables 1; 2).

these forms to perceive low frequency sounds. A conclusion consistent with the characteristics of the cochlear recess in these taxa (Luo et al. 1995). Independently of the auditory capabilities of non-mammaliaform cynodonts, they do not possess any lever system in the middle ear as observed in extant tetrapods with mono- or tri-ossicular tympanic ears (see also Gaetano \& Abdala 2015). The configuration of the articular-quadrate-stapes complex in non-mammaliaform cynodonts precluded a primary or secondary lever system as observed in extant tetrapods (see Manley \& Sienknecht 2013: figure 2.1). In the synapsid lineage, a middle ear lever system only appeared among mammaliaforms, when the incus and malleus were included in the middle ear, after losing their participation in the suspensorium. In mammaliaforms, the middle ear bones show a remarkable reduction in size and, concomitantly, in mass, which had a key significance in the mobility of the bones. This scenario is consistent with the high intraspecific variability in the stapes of Galesaurus and Thrinaxodon that suggests that this element might not have great influence on the hearing capabilities. It appears to us that whereas the stapes of non-mammaliaform cynodonts, in particular Thrinaxodon and Galesaurus, show features that could be interpreted as for tympanic hearing (i.e., it is gracile when compared to more basal synapsids, is horizontally oriented, and has a relatively small stapedial footplate), the articular-quadrate-stapes complex configuration precluded a functional lever system able to amplify the sound waves received from a hypothetical large tympanic membrane. Perhaps, cynodonts are showing an intermediate condition between inertial and tympanic hearing.

\section{CONCLUSIONS}

The present study represents the first comprehensive analysis of the stapedial anatomy variation in an ontogenetic framework considering a large sample of individuals of two species of extinct cynodonts: Thrinaxodon liorhinus and Galesaurus planiceps. Stapes growth models are different in the two species. Galesaurus shows a positive allometry on the lateromedial length and also on the anteroposterior width, although in this latter case only under RMA method. In Thrinaxodon there is a negative allometry in the anteroposterior width of the stapes but the lateromedial length is not statistically significant different from one (isometry). Two Thrinaxodon specimens (of different sizes) show a circular to near-circular stapedial foramen departing from the ellipsoid to ovoid morphologies represented in the remaining of the sample and also observed in the majority of non-mammaliaform cynodonts in which the stapes is known. There is a huge variation in the morphology of the stapes of the two largest specimens of Galesaurus concerning the anteroposterior width of the bone and development of stapedial foramen among others. These two large Galesaurus specimens are also remarkable because they are the only in which the posterior crus is wider than the anterior, in opposition to the condition in remaining specimens of the sample. Values on the stapedial footplates of Thrinaxodon and Galesaurus (generally interpreted as fossorials to semifossorials) are much smaller than those of small fossorial dicynodonts (with skull size values closer to that of Thrinaxodon and Galesaurus), indicating that this variable is not a clear cut to identify fossorialism across therapsids. 


\section{Acknowledgements}

We are thankful to E. Gaffney (AMNH), N. Mchunu (CGP), B. Zipfel and S. Jirah (ESI), H. Sues (NMNH), E. Butler (NMQR), the Rubidge family (RC), C. Browning, Z. Erasmus and Z. Skosan (SAM), H. Fourie (TM), M. Lowe (UMCZ) and P. Holroyd (UCMP) for access to specimens and loan for preparation. M. Lowe also helped us by sending photographs of a Galesaurus specimen under his care. We thank C. Dube (ESI) for the preparation of some of the specimens. We are grateful to the staff of the ID17 and ID19 beamlines at the European Synchrotron Radiation Facility for the CT-scan images of Thrinaxodon stapes. We thank V. Fernandez (NHMUK) for providing CT-scan images of $\mathrm{BP} / 1 / 5372$ and BP/1/7199, J. Meng, N. Wong and J. Hopson for helping us with photographs of specimens under their care, and M. J. Mason for information on middle ear of living mammals and his very valuable insight on middle ear functionality. We thank L. Luci (IDEAN) for her help with the statistical methods and C. Cataldo (IDEAN) for aiding us with the translation into French of the abstract and captions. Reviews by Z. Luo and an anonymous referee are especially recognized. Funding for the research was provided by PAST, National Research Foundation (NRF), African Origins Platform and the DST/NRF Centre of Excellence for Palaeosciences, South Africa, Bi-National Cooperation Project between South Africa (Department of Science and Technology to B. Rubidge) and Argentina (Ministerio de Ciencia, Técnica e Innovación Productiva to C. Marsicano), Consejo Nacional de Investigaciones Científicas y Técnicas, Argentina (CONICET; PIP11220150100760CO to L.C.G.), and Agencia Nacional de Promoción Científica y Tecnológica, Argentina (PICT 2017-1487 to L.C.G.; PICT 2015-2389 to N. Giannini; PICT 2017-2159 to M. de la Fuente). This is L.C.G.'s R-302 contribution to the IDEAN.

\section{REFERENCES}

ABDALA F. 2003. - Galesaurid cynodonts from the Early Triassic of South Africa: another example of conflicting distribution of characters in non-mammalian cynodonts. South African Journal of Science 99: 95-96.

AbDala F., Cisneros J. C. \& Smith R. M. H. 2006. - Faunal aggregation in the Early Triassic Karoo Basin: earliest evidence of shelter-sharing among tetrapods? Palaios 21: 507-512. https:// doi.org/10.2110/palo.2005.P06-001R

AbDala F. \& Ribeiro A. M. 2010. - Distribution and diversity patterns of Triassic cynodonts (Therapsida, Cynodontia) in Gondwana. Palaeogeography, Palaeoclimatology, Palaeoecology 286: 202-217. https://doi.org/10.1016/j.palaeo.2010.01.011

Abdala F., Gaetano L. C., Smith R. M. H. \& Rubidge B. S. 2019. A new large cynodont from the late Permian (Lopingian) of the South African Karoo Basin, and its phylogenetic significance. Zoological Journal of the Linnean Society: 983-1005. https://doi. org/10.1093/zoolinnean/zlz004

AbDala F., JASINOSKI J. C. \& FeRnANDEZ V. 2013. - Ontogeny of the Early Triassic cynodont Thrinaxodon liorhinus (Therapsida): dental morphology and replacement. Journal of Vertebrate Paleontology 33: 1408-1431. https://doi.org/10.1080/02724634.2013.775140

ALLIN E. F. 1975. — Evolution of the mammalian middle ear.Journal of Morphology 147: 403-438. https://doi.org/10.1002/jmor.1051470404
Allin E. F. \& Hopson J. A. 1992. - Evolution of the auditory system in Synapsida ("mammal-like reptiles" and primitive mammals) as seen in the fossil record, in WeBster D. B., FAY R. R. \& POPPER A. N. (eds), The Evolutionary Biology of Hearing. SpringerVerlag, New York: 587-614.

Botha J. \& Chinsamy A. 2005. - Growth patterns of Thrinaxodon liorhinus, a non-mammalian cynodont from the lower Triassic of South Africa. Palaeontology 48: 385-394. https://doi. org/10.1111/j.1475-4983.2005.00447.x

Botha-BRinK J., ABDALA F. \& ChInSAMY A. 2012. - Bone histology and radiation of Permo-Jurassic non-mammaliaform cynodonts, in Chinsamy A. (ed.), The Forerunners of Mammals: Radiation. Biology. Histology. Indiana University Press, Bloomington: 223-246.

BRINK A. S. 1955. - Note on a very tiny specimen of Thrinaxodon liorhinus. Palaeontologia africana 3: 73-76. http://hdl.handle. net $10539 / 14873$

BRINK A. S. 1965. - On two new specimens of Lystrosaurus-Zone cynodonts. Palaeontologia africana 9: 107-122. http://hdl.handle. net/10539/16060

Broom R. 1932. - The cynodont genus Galesaurus. Annals of the Natal Museum 7: 61-66.

BroOM R. 1938. - On the structure of the skull of the cynodont, Thrinaxodon liorhinus, Seeley. Annals of the Transvaal Museum 19: 263-269.

Brownell W. E., Bader C. R., Bertrand D. \& De Ribaupierre Y. 1985. - Evoked mechanical responses of isolated cochlear outer hair cells. Science 227: 194-196. https://doi.org/10.1126/ science. 3966153

BuTLER E. 2009. - The postcranial skeleton of the Early Triassic non-mammalian Cynodont Galesaurus planiceps: Implications for biology and lifestyle. Unpublished MSc thesis, University of the Free State, Bloemfontein, $152 \mathrm{p}$.

Butler E., Abdala F. \& Botha-Brink J. 2019. — Postcranial morphology of the Early Triassic epicynodont Galesaurus planiceps (Owen) from the Karoo Basin, South Africa. Papers in Palaeontology 5: 1-32. https://doi.org/10.1002/spp2.1220

ClaCK J. A. 2002. - Patterns and processes in the early evolution of the tetrapod ear. Journal of Neurobiology 53: 251-264. https:// doi.org/10.1002/neu.10129

COlBerT E. H. \& MORALES M. 1991. - Evolution of the Vertebrates: A History of the Backboned Animals Through Time. Wiley-Liss, New York, 470 p.

Crompton A. W. 1963. - Tooth replacement in the cynodont Thrinaxodon liorhinus Seeley. Annals of the South African Museum 46: 479-521. https://www.biodiversitylibrary.org/page/40867347

Damiani R., Modesto S.,Yates A. \& NeVEling J. 2003. — Earliest evidence of cynodont burrowing. Proceedings of the Royal Society B 270: 1747-1751. https://doi.org/10.1098/rspb.2003.2427

DORAN A. H. G. 1878. - Morphology of the mammalian ossicula auditûs. Transactions of the Linnean Society of London, 2nd Ser 1: 371-497.

ESTES R. 1961. - Cranial anatomy of the cynodont reptile Thrinaxodon liorhinus. Bulletin of the Museum of Comparative Zoology 125: $165-180$

Fay J. P., PuRIA S. \& STEELE C. R. 2006. - The discordant eardrum. Proceedings of the National Academy of Sciences. 103: 19743-19748. https://doi.org/10.1073/pnas.0603898104

Fernandez V., Abdala F., Carlson K. J., CoOK D. C., Rubidge B. S., YATES A. \& TAFFOREAU P. 2013. - Synchrotron reveals Early Triassic odd couple: injured amphibian and aestivating therapsid share burrow. PLoS One 8: e64978. https://doi.org/10.1371/ journal.pone. 0064978

FOURIE S. 1974. - The cranial morphology of Thrinaxodon liorhinus Seeley. Annals of the South African Museum 65: 337-400.

FunNELl W. R. \& LASZLO C. A. 1982. - A critical review of experimental observations on ear-drum structure and function. Journal of Otolaryngology. Related specialties 44: 181-205. https:// doi.org/10.1159/000275593 
Gaetano L. C. \& AbDala F. 2015. - The stapes of gomphodont cynodonts: insights into the middle ear structure of nonmammaliaform cynodonts. PLoS One 10: e0131174. https:// doi.org/10.1371/journal.pone.0131174

GaETANo L. C. \& ABDala F. 2017. - El oído medio de los cinodontes basales, in AbDala V., Manzano A., Vasallo A. (Comp.), I Taller de Morfología de Vertebrados. Editorial de la Universidad Nacional de Mar del Plata, Buenos Aires: 35-57.

Gow C. E. 1985. - Dentitions of juvenile Thrinaxodon (Reptilia: Cynodontia) and the origin of mammalian diphyodonty. Annals of the South African Geological Survey 19: 1-17.

Hammer Ø. 2019. - Past, Palaeontological Statistics, version 3.25. Reference Manual. Natural History Museum, Oslo, 275 p.

Hammer Ø., Harper D. A. T. \& Ryan P. D. 2001. — Past: Paleontological statistics software package for education and data analysis. Paleontologia Electronica 4: 1-9.

HaUGHTON S. H. 1924. — On Cynodontia from the Middle Beaufort beds of Harrismith, Orange Free State. Annals of the Transvaal Museum 11: 74-92. https://journals.co.za/doi/abs/10.10520/ AJA00411752_719

HoPSON J. A. 1966 . - The origin of the mammalian middle ear. American Zoologist 6: 437-450. https://doi.org/10.1093/icb/6.3.437

JASINOSKI S. C. \& ABDALA F. 2017a. - Aggregations and parental care in the Early Triassic basal cynodonts Galesaurus planiceps and Thrinaxodon liorhinus. PeerJ 5: e2875. https://doi.org/10.7717/ peerj. 2875

JASINOSKI S. C. \& ABDALA F. 2017b. - Cranial ontogeny of the Early Triassic basal cynodont Galesaurus planiceps. The Anatomical Record 300: 353-381. https://doi.org/10.1002/ar.23473

JASINOSKI S. C. \& ABDALA F. \& FERNANDEZ V. 2015. — Ontogeny of the Early Triassic cynodont Thrinaxodon liorhinus (Therapsida) cranial morphology. The Anatomical Record 298: 1440-1464. https://doi.org/10.1002/ar.23116

JENKINS F. A. 1971. - The postcranial skeleton of African cynodonts. Bulletin Peabody Museum of Natural History 36: 1-216.

Kemp T. S. 1969. - The atlas-axis complex of the mammallike reptiles. Journal of Zoology159: 223-248. https://doi. org/10.1111/j.1469-7998.1969.tb03079.x

KemP T. S. 2007. - Acoustic transformer function of the postdentary bones and quadrate of a nonmammalian cynodont. Journal of Vertebrate Paleontology 27: 431-441. https://doi.org/10.1671/02724634(2007)27[431:ATFOTP]2.0.CO;2

Kermack D. M. \& KermaCK K. A. 1984. - The evolution of mammalian characters. Croom Helm, London \& Sydney, Kapitan Szabo Publishers, Washington D. C., 149 p.

Kermack D. M. \& MussetT F. 1983. - The ear in mammal-like reptiles and early mammals. Acta Palaeontologica Polonica 28: $147-158$

Kümmell S. 2009. — Die Digiti der Synapsida: Anatomie, Evolution und Konstruktionsmorphologie. PhD thesis, University of Witten, Herdecke, Shaker-Verlag, Aachen, 424 p.

KÜMMELL S. B. \& FREY E. 2012. - What digits tell us about digging, running and climbing in recent and fossil Synapsida, $10^{\text {th }}$ Annual Meeting of the European Association of Vertebrate Palaeontologists, Fundación Conjunto Paleontológico de Teruel, Teruel: 117-118

LAAß M. 2014. - Bone-conduction hearing and seismic sensitivity of the Late Permian anomodont Kawingasaurus fossilis. Journal of Morphology 276: 121-143. https://doi.org/10.1002/jmor.20325

LAAß M. 2016. - The origins of the cochlea and impedance matching hearing in synapsids. Acta Palaeontologica Polonica 61: 267280. https://doi.org/10.4202/app.00140.2014

LiM D. J. 1968. - Tympanic membrane. Electron microscopic observation. I: pars tensa. Acta Oto-Laryngologica 66: 181-198. https://doi.org/10.3109/00016486809126286

LOMBARD R. E. \& BOLT J. R. 1979. — Evolution of the tetrapod ear: an analysis and reinterpretation. Biological Journal of the Linnean Society 11: 19-76. https://doi.org/10.1111/j.1095-8312.1979. tb00027.x
Luo Z.-X. 2011. - Developmental patterns in Mesozoic evolution of mammal ears. Annual Review of Ecology, Evolution, and Systematics 42: 355-80. https://doi.org/10.1146/annurev-ecolsys-032511-142302

LuO Z.-X. \& CROMPTON A. W. 1994. - Transformation of the quadrate (incus) through the transition from non-mammalian cynodonts to mammals. Journal of Vertebrate Paleontology 14: 341-374. https://doi.org/10.1080/02724634.1994.10011564

LUO Z-X., CROMPTON A. W. \& LuCAS S. G. 1995. — Evolutionary origins of the mammalian promontorium and cochlea. Journal of Vertebrate Paleontology 15: 113-121. https://doi.org/10.1080 /02724634.1995.10011211

MAIER W. \& RUF I. 2016. — Evolution of the mammalian middle ear: a historical review. Journal of Anatomy 228: 270-283. https:// doi.org/10.1111/joa.12379

Maier W. \& VAN DEN HeEver J. 2002. — Middle ear structures in the Permian Glanosuchus sp. (Therocephalia, Therapsida), based on thin sections. Mitteilungen des Museums für Naturkunde Berlin. Geowissenschaftliche Reihe 5: 309-318.

MANLEY G. A. 1971. - Some aspects of the evolution of hearing in vertebrates. Nature 230: 506-509.

MANLEY G. A. 1972. - Frequency response of the middle ear of geckos. Journal of Comparative Physiology 81: 251-258. https:// doi.org/10.1007/BF00693630

MANLEY G. A. 1973. - A review of some current concepts of the functional evolution of the ear in terrestrial vertebrates. Evolution 26: 608-621. https://doi.org/10.1111/j.1558-5646.1972. tb01968.x

Manley G. A. \& Sienknecht U. J. 2013. - The Evolution and Development of Middle Ears in Land Vertebrates, in PURIA, S, FAY R. R., POPper A. (eds), The Middle Ear: Science, Otosurgery, and Technology. Springer Handbook of Auditory Research, New York: 46: 7-30.

Mason M. J. 2001. - Middle ear structures in fossorial mammals: a comparison with non-fossorial species. Journal of Zoology 255: 467-486. https://doi.org/10.1017/S0952836901001558

MAsOn M. J. 2003. - Morphology of the middle ear of golden moles (Chrysochloridae). Journal of Zoology 260: 391-403. https:// doi.org/10.1017/S095283690300387X

Mason M. J., LaI F. W. S., LI, J-G. \& Nevo E. 2010. — Middle ear structure and bone conduction in Spalax, Eospalax, and Tachyoryctes mole-rats (Rodentia: Spalacidae). Journal of Morphology 271: 462-472. https://doi.org/10.1002/jmor.10810

Masterton, B, Heffner H. \& Ravizza R. 1969. - The evolution of human hearing. The Journal of the Acoustical Society of America 45: 966-985. https://doi.org/10.1121/1.1911574

MENG J. 1992. — The stapes of Lambdopsalis Bulla (Multituberculata) and transformational analyses on some stapedial features in mammaliaformes. Journal of Vertebrate Paleontology 12: 459-471. https://doi.org/10.1080/02724634.1992.10011474

MENG J., Bi S., ZHENG X. \& WANG X. 2018. — Ear ossicle morphology of the Jurassic euharamiyidan Arboroharamiya and evolution of mammalian middle ear. Journal of Morphology 279: 441-457. https://doi.org/10.1002/jmor.20565

OlsON E. C. 1944. - Origin of mammals based upon cranial morphology of the therapsid suborders. Geological Society of America. Special papers 55: 136.

Osborn J. W. \& CROMPTON A. W. 1973. - The evolution of mammalian from reptilian dentitions. Breviora 399: 1-18.

OwEN R. 1859. - On some reptilian remains from South Africa. The Edinburgh new philosophical journal 10: 289-291.

OWEN R. 1860. - On some reptilian fossils from South Africa. The Quarterly journal of the Geological Society of London 16: 49-63. https://doi.org/10.1144/GSL.JGS.1860.016.01-02.07

OWEN R. 1887. - On the skull and dentition of a Triassic saurian (Galesaurus planiceps, Ow.). The Quarterly Journal of the Geological Society of London 43: 1-6. https://doi.org/10.1144/GSL. JGS.1887.043.01-04.03 
PANKO L. J. 2001. - Evolution and functional morphology of the axial skeleton in the Synapsida. Unpublished $\mathrm{PhD}$ thesis, The University of Chicago, Chicago.

PARK K. \& CHOUnG Y.-H. 2009. - Isolated congenital ossicular anomalies. Acta Oto-Laryngologica 129: 419-422. https://doi. org/10.1080/00016480802587846

PARRINGTON F. R. 1934. - On the cynodont genus Galesaurus, with a note on the functional significance of the changes in the evolution of the theriodont skull. Annals and Magazine of Natural History 10: 38-67. https://doi.org/10.1080/00222933408654791

PARRINGTON F. R. 1936. — On the tooth-replacement in Theriodont reptiles. Philosophical Transactions of the Royal Society $B$ 226: 121-142. https://doi.org/10.1098/rstb.1936.0005

PARRINGTON F. R. 1946. - On the cranial anatomy of cynodonts. Proceedings of the Zoological Society of London 116: 181-197. https://doi.org/10.1111/j.1096-3642.1946.tb00116.x

PARRINGTON F. R. 1979. - The evolution of the mammalian middle and outer ears: a personal review. Biological Reviews Cambridge Philosophical Society 54: 369-387. https://doi.org/10.1111/j.1469185X.1979.tb00842.x

Patterson B \& Olson E. C. 1961. - A triconodont mammal from the Triassic of Yunnan. International Colloquium on the Evolution of Lower and Non Specialized Mammals. Koninklijke Vlaamse Academir voor Wetenschappen, Letteren en Schone Kunsten can Belgie: 129-191.

PuRIA S. \& STEELE C. 2010. - Tympanic-membrane and malleusincus-complex co-adaptations for high-frequency hearing in mammals. Hearing Research 263: 183-190. https://doi.org/10.1016/j. heares.2009.10.013

Pusch L. C., Kammerer C. F. \& Fröвisch J. 2019. - Cranial anatomy of the early cynodont Galesaurus planiceps and the origin of mammalian endocranial characters. Journal of Anatomy 234: 592-621. https://doi.org/10.1111/joa.12958

RabbitT R. D. \& Holmes M. H. 1986. - A fibrous dynamic continuum model of the tympanic membrane. The Journal of the Acoustical Society of America 80: 1716-1728. https://doi. org/10.1121/1.394284

Ramírez-Chaves H. E., Wroe S. W., Selwood L., Hinds L. A., Leigh C., Koyabu D., Kardjilov N. \& WeisbeCKer V. 2016. Mammalian development does not recapitulate suspected key transformations in the evolutionary detachment of the mammalian middle ear. Proceedings of the Zoological Society of London B 284: e20162416. https://doi.org/10.1098/rspb.2015.2606
Rigney H. W. 1938. — The morphology of the skull of a young Galesaurus planiceps and related forms.Journal of Morphology 63 : 491-529. https://doi.org/10.1002/jmor.1050630305

Rowe T. B. 1988. - Definition, diagnosis, and origin of Mammalia. Journal of Vertebrate Paleontology 8: 241-264. https://doi. org/10.1080/02724634.1988.10011708

Rowe T. B., CARLSON W. \& BOTTORFF W. 1993. - Thrinaxodon: digital atlas of the skull. CD-ROM (First edition, for MS-DOS platform), University of Texas Press, 623 megabytes.

SEELEY H. G. 1894. - Researches on the structure, organization, and classification of the fossil Reptilia. Part IX. Section 1. On the Theriosuchia. Philosophical Transactions of the Royal Society $B$ 185: 987-1018. https://doi.org/10.1080/00222939408677718

SMITH \& BOTHA-BRINK 2014 - Anatomy of a mass extinction: Sedimentological and taphonomic evidence for drought-induced die-offs at the Permo-Triassic boundary in the main Karoo Basin, South Africa. Palaeogeography, Palaeoclimatology, Palaeoecology 396: 99-118. https://doi.org/10.1016/j.palaeo.2014.01.002

TAYLOR G. D. 1969. - Evolution of the ear. Laryngoscope 79: 638651. https://doi.org/10.1288/00005537-196904000-00007

TUMARKIN A. 1955. - On the evolution of the auditory conducting apparatus. Evolution 9: 221-242. https://doi. org/10.1111/j.1558-5646.1955.tb01534.x

TUMARKIN A. 1968. - The evolution of the auditory conducting apparatus in terrestrial vertebrates, in DE REUCK A. S. \& KNIGHT J. (eds), Ciba Foundation Symposium on Hearing Mechanisms in Vertebrates. Churchill, London: 18-37.

VAN HEERDEN J. 1972. - Interspecific variation and growth changes in the cynodont reptile Thrinaxodon liorhinus. Navorsinge van die Nasionale Museum 2: 307-347.

WaTSOND.M.S. 1920._-On the Cynodontia. Annals \& magazine of natural history 6: 506-524. https://doi.org/10.1080/00222932008632477

WATSON D. M. S. 1953. - Evolution of the mammalian ear. Evolution 7: 159-177. https://doi.org/10.1111/j.1558-5646.1953. tb00074.x

WiBLE J. R. 1991. — Origin of Mammalia: the craniodental evidence reexamined. Journal of Vertebrate Paleontology 11: 1-28. https:// doi.org/10.1080/02724634.1991.10011372

Wible J. R. \& Hopson J. A. 1993. - Basicranial evidence for early mammal phylogeny, in Szalay F. S., NovaceK M. J \&, MCKENNA M. C. (eds), Mammal phylogeny: Mesozoic differentiation, multituberculates, monotremes, early therians, and marsupials. Springer-Verlag, New York: 45-62.

Submitted on 16 August 2019; accepted on 6 January 2020; published on 8 February 2021. 